College of William \& Mary Law School William \& Mary Law School Scholarship Repository

2000

\title{
Assessing the Practicality and Constitutionality of Alaska's Split-Recovery Punitive Damages Statute
}

Scott Dodson

dodsons@uchastings.edu

\section{Repository Citation}

Dodson, Scott, "Assessing the Practicality and Constitutionality of Alaska's Split-Recovery Punitive Damages Statute" (2000). Faculty Publications. 719.

https://scholarship.law.wm.edu/facpubs/719

Copyright c 2000 by the authors. This article is brought to you by the William \& Mary Law School Scholarship Repository. https://scholarship.law.wm.edu/facpubs 


\section{Notes \\ ASSESSING THE PRACTICALITY AND CONSTITUTIONALITY OF ALASKA'S SPLIT- RECOVERY PUNITIVE DAMAGES STATUTE}

\section{SCOTT DODSON}

In 1997, Alaska responded to its "reputation[] for unusually high punitive awards"1 by aniending its punitive damages statute. ${ }^{2}$ Under the new Alaska "split-recovery" statute, $50 \%$ of all punitive damages awarded to civil plaintiffs is to be "deposited into the general fund of the state." ${ }^{3}$

Fear of tort liability has long plagued American businesses. ${ }^{4}$ In recent years, however, the perception has been that "punitive damages are skyrocketing" and are "run[ning] wild." Regardless of whether this perception is accurate, ${ }^{7}$ there can be no doubt that fears

1. Rob Stapleton, Alaska Commercial Aviation Welcomes Tort Reform; Critics Cautious, ALASKA J. COM., June 16, 1997, at 6.

2. See Act of May 9, 1997, ch. 26, \$10, 1997 Alaska Sess. Laws 1, 5.

3. AlasKa STAT. $\S 09.17 .020(j)$ (Michie 1998).

4. See, e.g., Brian Porter, Tort Reform Must Be Meaningful to Be Effective, ANCHORAGE DAILY NEWS, Mar. 28, 1997, at B10 ("The mere threat of unlimited subjective damage claims, such as punitive damages and damages for 'disfigurement or physical impairment,' has the in terrorem ... effect of extorting oversized settlements from partially at fault to totally innocent defendants.").

5. Browning-Ferris Indus., Inc. v. Kelco Disposal, Inc., 492 U.S. 257, 282 (1989) ( $\mathrm{O}^{\prime}$ Connor, J., concurring in part and dissenting in part).

6. Pacific Mut. Life Ins. Co. v. Haslip, 499 U.S. 1, 18 (1991).

7. See Theodore Eisenberg et al., The Predictability of Punitive Damages, 26 J. LEGAL STUD. 623, 649 (1997) ("Our data, which consist of judgments entered by judges after jury verdicts, suggest an essential rationality and connection to compensatory dainages at the trial court level."); Michael L. Rustad, Unraveling Punitive Damages: Current Data and Further Inquiry, 1998 WIS. L. REV. 15, 54 ("All [empirical studies] conclude that punitive damages verdicts are rare."). See generally Stephen Daniels \& Joanne Martin, Myth and Reality in Punitive Damages, 75 MINN. L. REV. 1 (1990) (finding that punitive damages are awarded infrequently and in moderate amounts). 
of high punitive verdicts have fueled a strong push for tort reform at both the state ${ }^{8}$ and national levels.'

States have tried to allay these fears in a number of ways. Many have imposed limits on the size of punitive awards in the form of a flat dollar cap or a ratio to the compensatory award. ${ }^{10}$ Commentators have criticized caps and ratios, however, for undermining the punishment and deterrence effects of pumitive damages, ${ }^{11}$ while still allowing the plaintiff to reap a windfall gain. With these concerns in mind, some states have implemented a novel concept-the sphtrecovery statute. ${ }^{12}$

8. See, e.g., Porter, supra note 4 (urging tort reform measures for Alaska).

9. See, e.g., Common Sense Product Liability and Legal Reform Act of 1996, H.R. 956, 104th Cong. \& 2(b)(2) (1996) (intending, among other things, to "plac[e] reasonable limits on damages over and above the actual damages suffered by a claimant") (vetoed by 142 CoNG. REC. H4425-06 (daily ed. May 6, 1996)); Michael L. Rustad, Nationalizing Tort Law: The Republican Attack on Women, Blue Collar Workers and Consumers, 48 RUTGERS L. REV. 673, 674 (1996) (discussing tort reform measures proposed in Congress in the wake of the 1994 Republican electoral victories).

10. Caps and ratios preclude the entry of judgment of the surplus of a punitive verdict exceeding a certain amount. For caps, the certain amount is a fixed number. For ratios, the amount is some multiple of the coinpensatory damages. For example, New Jersey limits a punitive award to five times the compensatory damages or $\$ 350,000$, whichever is greater. See N.J. STAT. ANN. § 2A:15-5.14(b) (West Supp. 1999). At least 22 states have enacted legislative caps or ratios on punitive damages awards. See Nicholas M. Miller, Note, 'Tis Better to Give Than to Receive: Charitable Donations of Medical Malpractice Punitive Damages, 12 J.L. \& HEALTH 141,145 n.34 (1998).

11. See Justice Janie L. Shores, A Suggestion for Limited Tort Reform: Allocation of Punitive Damage Awards to Eliminate Windfalls, 44 ALA. L. REV. 61, 87 (1992) ("Harmful conduct may then be underdeterred by legislatively mandated caps on punitive awards."); Note, 'Common Sense' Legislation: The Birth of Neoclassical Tort Reform, 109 HARV. L. REV. 1765, 1774 (1996) (concluding that "a cap may result in underdeterrence"); Miller, supra note 10, at 158 ("Caps ... prevent imposition of punitive damages on especially wealthy or especially egregious wrongdoers necessary to sufficiently punish or adequately deter wrongful conduct."). But see Stephen R. McAllister, A Pragmatic Approach to the Eighth Amendment and Punitive Damages, 43 U. KAN. L. REV. 761, 790-97 (1995) (endorsing ratios or proportionality limitations on punitive damages).

12. The following are the original statute enactments followed by their current status: Act of May 9, 1997, ch. 26, § 10, 1997 Alaska Sess. Laws 1, 5 (codified by ALASKA STAT. $\$ 09.17 .020$ (Michie 1998)); Act of May 16, 1986, ch. 106, 1986 Colo. Sess. Laws 675 (repealed by Act of March 9, 1995, ch. 6, 1995 Colo. Sess. Laws 14); Act of June 26, 1986, ch. 160, § 52, 1986 Fla. Laws 749 (repealed 1997); Tort Reform Act of 1987, No. 672, 1987 Ga. Laws 915 (codified with amendments by GA. CODE ANN. \$ 51-12-5.1 (Supp. 1999)); 1989 Ill. Laws 1431 (codified by 735 ILL. COMP. STAT. ANN. 5/2-1207 (West Supp. 1999)); Act of March 6, 1998, \$ 47, 1998 Ind. Acts 317 (codified at IND. CODE ANN. \$ 34-51-3-6 (Michie 1998)); Act of May 22, 1986, ch. 1211, 1986 Iowa Acts 313 (codified with amendinents by IOWA CODE ANN. $\$ 668$ A.1 (West 1998)); Act of April 26, 1985, ch. 197, \& 2(e), 1985 Kan. Sess. Laws 951, 953 (repealed 1988); 1996 Mo. Laws $869 \$$ C (codified by MO. ANN. STAT. $\$ 537.675$ (West Supp. 2000)); Act of April 10, 1992, cl. $55, \S 393,1992$ N.Y. Laws 2286 (also set date of repeal, Act of April 10, 1992, ch. 55, § 
Split-recovery statutes attempt to reduce some of the plaintiff's windfall by allocating part of the punitive award to the state. ${ }^{13} \mathrm{Al}-$ though the plaintiff shares in the award to compensate her for bringing the punitive claim in the first place, ${ }^{14}$ the state receives the balance to use for the public benefit. ${ }^{15}$ Since 1985 , twelve states have enacted split-recovery statutes. ${ }^{16}$ Some of those statutes lave been repealed, ${ }^{17}$ otliers have been scrutinized by the courts, ${ }^{18}$ and most have been analyzed by commentators. ${ }^{19}$ As the newest entrant in the splitrecovery arena, the Alaska statute stands alone as the only one yet untouched by legal critique.

This Note evaluates the practicality and constitutionality of Alaska's split-recovery statute. Part I reviews the nature and purpose of punitive danuages and the statutory provisions Alaska has enacted to enhance their effectiveness. It submits that Alaska's split-recovery statute effectively addresses one inherent problem of pumitive damages: the "plaintiff's windfall." This Part also discusses the statute's

427(dd), 1992 N.Y. Laws 2304); Act of July 17, 1987, ch. 774, § 3, 1987 Or. Laws 1570, 1571 (codified with amendments by OR. Rev. STAT. $\$ 18.540$ (Supp. 1996)); An Act Relating to Punitive Damages, ch. 237, § 1, 1989 Utah Laws 717 (codified by UTAH CODE ANN. § 78-18-1 (1996)).

13. See, e.g., Charles F.G. Parkinson, Note, $A$ Shift in the Windfall: An Analysis of Indiana's Punitive Damages Allocation Statute and the Recovery of Attorney's Fees Under the Particular Services Clause, 32 VAL. U. L. REv, 923, 943-44 (1998) (describing split-recovery statutes).

14. See Smith v. Wade, 461 U.S. 30, 58 (1983) (Rehnquist, J., dissenting) ("[P]unitive damages are justified as a "bounty' that encourages private lawsuits seeking to assert legal rights."); Alison D. Johnson, Note, Crookston v. Fire Insurance Exchange and the Utah Punitive Damage Act: Toward a Sounder Law of Punitive Damages?, 1993 UTAH L. REv. 513, 535 ("The prospect of receiving a punitive damages award encourages individuals to uphold legal norms by bringing suit when the defendant's conduct was egregious."); Nathan C. Prater, Comment, Punitive Damages in Alabama: A Proposal for Reform, 26 CUMB. L. REv. 1005, 1033-34 (1996) ("Conduct that is unacceptable to society does not necessarily result im substantial damages. Consequently, if punitive damages were not available, plaintiffs would have no incentive to bring tort actions, and there would be no deterrence of wrougful conduct." (footnote omitted)).

15. See E. Jeffrey Grube, Note, Punitive Damages: A Misplaced Remedy, 66 S. CAL. L. REV. 842, 854 (1993) ("[S]ociety could put punitive damages awards to better use than allowing individual civil plaintiffs windfall recoveries.").

16. See supra note 12 .

17. See Act of March 9, 1995, ch. 6, 1995 Colo. Sess. Laws 14; Act of May 24, 1997, ch. 94, \$ 16, 1997 Fla. Laws 571, 574; Act of July 1, 1988, ch. 209, § 6, 1988 Kan. Sess. Laws 1272; Act of April 10, 1992, ch. 55, § 427(dd), 1992 N.Y. Laws 2304.

18. See Kirk v. Denver Publ'g Co., 818 P.2d 262 (Colo. 1991); Gordon v. State, 608 So. 2d 800 (Fla. 1992) (per curiam); Mack Trucks, Inc. v. Conkle, 436 S.E.2d 635 (Ga. 1993); Spaur v. Owens-Corning Fiberglas Corp., 510 N.W.2d 854 (Iowa 1994); Fust v. Attorney Gen., 947 S.W.2d 424 (Mo. 1997) (en banc); Tenold v. Weyerhaeuser Co., 873 P.2d 413 (Or. Ct. App. 1994).

19. See, e.g., Shores, supra note 11, passim; Grube supra note 15, passim. 
effect on related issues such as settlement incentives and ultimately concludes that Alaska's statute is a practical and beneficial tort reform measure. Part II then examines several possible constitutional challenges to the statute, ultimately concluding that it should survive constitutional scrutiny.

\section{ASSESSING THE STATUTE'S DESIRABILITY}

\section{A. The Trouble with Punitives}

Puntive damages have been a part of American jurisprudence smce the country's inception. ${ }^{20}$ The Supreme Court has justified their imposition "to further a State's legitimate interests in punishing unlawful conduct and deterring its repetition." ${ }^{, 21}$ The Restatement (Second) of Torts echoes this dual purpose, ${ }^{22}$ legal scholars overwhelmingly concur, ${ }^{23}$ and most states have followed suit, ${ }^{24}$ Alaska

20. See Coryell v. Colbaugh, 1 N.J.L. 90,91 (1791) (holding that the jury in a breach of promise to marry case should not "estimate the damages by any particular proof of suffering or actual loss; but [should] give damages for example's sake, to prevent such offences in the future"). In fact, the use of punitive damages has ancient roots, see 1 LINDA L. SCHLUETER \& KENNETH R. REDDEN, PUNITIVE DAMAGES 1-5 (3d ed. 1995) (discussing the use of punitive damages in various ancient codes); Shores, supra note 11, at 62-63 (discussing the use of punitive damages in The Bible and the Code of Hammurabi), and their use in Euglish law was established by the time of the Magna Carta in 1215, see WIILIAM SHARP MCKECHNIE, MAGNA CARTA: A COMMENTARY ON THE GREAT CHARTER OF KING JOHN 285 (2d ed. 1914) (discussing the practice of accepting "money in heu of vengeance"). For further discussion of the development of punitive damages in English law aud their introduction to American jurisprudence, see 1 SCHLUETER \& REDDEN, supra, at 5-17; Shores, supra note 11, at 63-69. The historical lineage is important because at least two Supreme Court Justices consider firm establishment and tradition dispositive, or nearly so, in due process cases. See Pacific Mut. Life Ins. Co. v. Haship, 499 U.S. 1, 27-28 (1991) (Scakia, J., concurring) (arguing that the fact that the "common-law system for awarding punitive damages is firmly rooted im our history" makes that system acceptable for due process purposes); id. at 40 (Kennedy, J., concurring) ("[T]he judgment of history should govern the outcoine in the case before us. Jury determination of punitive damages has such long and principled recognition as a central part of our system that no further evidence of its essential fairness or rationality ought to be deemed necessary.").

21. BMW of North Am., Inc. v. Gore, 517 U.S. 559, 568 (1996).

22. See RESTATEMENT (SECOND) OF TORTS $\$ 908(1)$ (1979) [hereinafter RESTATEMENT] ("Punitive damages are damages, other than compensatory or nominal damages, awarded against a person to punish him for his outrageous conduct and to deter him and others like him from similar conduct in the future.").

23. See, e.g., Joel Slawotsky, The Impropriety of Levying Punitive Damages on Innocent Successor Corporations, 38 DUQ. L. REV. 49, 62-63 (1999) (stating that the purposes of punitive damages are punishment and deterrence).

24. See, e.g., Montgomery Ward \& Co. v. Andrews, 736 P.2d 40, 43 (Colo. Ct. App. 1987) (stating that punitive damages serve the dual purposes of purnshment and deterrence); General Motors Corp. v. Moseley, 447 S.E.2d 302, 314 (Ga. Ct. App. 1994) (same); Honeywell v. Sterling Furniture Co., 797 P.2d 1019, 1021 (Or. 1990) (same). One court has held that punitive damages 
included..$^{25}$ As "quasi-criminal punishment," punitive daniages usually are assessed only in extreme cases when the defendant's conduct is particularly inalicious or reprehensible. ${ }^{26}$ Alaska, for example, imposes punitive damages only when the defendant's conduct "was outrageous, including acts done with inalice or bad notives"27 or acts evincing "reckless indifference to the interest of another person." 28

In addition to these theoretical justifications, ${ }^{29}$ punitive damages also provide a functional mducement to private hitigants to pursue punitive claims in the first place. ${ }^{30}$ Compensatory damages should make the injured plaintiff whole; $;^{31}$ punitive damages, on the otler

serve the additional purpose of compensating the plaintiff for losses "too remote to be considered as elements of strict compensation." Hofer v. Lavender, 679 S.W.2d 470, 474 (Tex. 1984). However, subsequeut opinions of the Texas Supreme Court have relied on the punishment and deterrence rationales and have disavowed any connection to compensation. See Transportation Ins. Co. v. Moriel, 879 S.W.2d 10, 16-17 (Tex. 1994); Cavnar v. Quahity Control Parking, Inc., 696 S.W.2d 549, 555-56 (Tex. 1985). Whether the compensation rationale of Hofer is an aberration, or is just selectively invoked, is an intriguing subject beyond the scope of this Note. See Joe McKay, Comment, Texas Public Policy on Insuring Punitive Damages: Time for a Fresh Look, 2 TEX. WESLEYAN L. REV. 205, 222-25 (1995) (arguing that Hofer merely created an exception enabling a plaintiff to recover damages froin the estate of a decedent wrongdoer). In contrast to Hofer, the United States Supreme Court has pointedly disclaimed any compensatory role for punitive damages. See Gertz v. Robert Welch, Inc., 418 U.S. 323, 350 (1974) (stating that pnnitive damages "are not compensation for injury," but "private fines levied by civil juries to punisli repreliensible conduct and to deter its future occurrence").

25. See Chizmar v. Mackie, 896 P.2d 196, 209 (Alaska 1995) ("Punitive damages serve two purposes: 'to punislt the wrongdoer and to deter the wrongdoer and others like him from repeating the offensive act."' (quoting State Farm Mut. Auto. Ins. Co. v. Weiford, 831 P.2d 1264, 1266 (Alaska 1992))); Portwood v. Copper Valley Elec. Ass'n, 785 P.2d 541, 543 (Alaska 1990) ("An award of puintive damages is imtended to punish and deter the tortfeasor, not to compensate the victim.").

26. See Pacific Mut. Life Ins. Co. v. Haslip, 499 U.S. 1, 54 (1991) (O'Connor, J., dissenting) ("[P]unitive damages are specifically designed to exact punishment in excess of actual larm to make clear that the defendant's misconduct was especially repreliensible.").

27. ALASKA STAT. $\$ 09.17 .020$ (b)(1) (Michie 1998).

28. Id. $\$ 09.17 .020(\mathrm{~b})(2)$.

29. Another inportant ancillary effect of punitive damages is the ability to address outrageous conduct not reachable through the criminal justice system. See Carlson v. Green, 446 U.S. 14, $22 \mathrm{n} .9$ (1980) ("[P]unitive damages may be the only significant remedy available in some $\S$ 1983 actions where constitutional rights are inaliciously violated but the victim cannot prove compensable imjury."); Luther v. Sliaw, 147 N.W. 18, 20 (Wis. 1914) (stating that punitive damages provide "recourse to, and confidence in, the courts of law by those wronged or oppressed by acts or practices not cognizable in, or not sufficiently punished, by the criminal law").

30. See Smith v. Wade, 461 U.S. 30, 58 (1983) (Rehnquist, J., dissenting) (stating that purntive dainages are justified by punishment, deterrence, and the provision of a bounty to encourage the assertion of legal rights in private lawsuits).

31. See RESTATEMENT, supra note $22, \$ 901 \mathrm{cmt}$. a (defining compensatory damages as those necessary to "put [the] imjured person in a position as nearly as possible equivalent to his position prior to the [ujury]"). 
hand, are not compensation..$^{32}$ Hence, without the expectation of additional remuneration, a fully compensated plaintiff has no reason to spend the time and money needed to prove that the defendant's conduct was so egregious as to warrant pumitive damages. ${ }^{33}$ In addition, a plaintiff with relatively small actual damages might forgo the entire suit without the prospect of punitive damages to make the litigation worthwhile. In either case, it is the prospect of receiving pumitive damages that enables the plamtiff to address the defendant's egregious wrongs. ${ }^{34}$ Consequently, any punitive award traditionally inures to the plaintiff as a reward for acting as a private attorney general.

Despite the virtues of pumitive damages, they are not without controversy. In 1873, for example, the New Hampshire Suprenie Court decreed, "The idea of [punitive damages] is wrong. It is a monstrous heresy. It is an unsightly and an unhealthy excrescence, deforming the symmetry of the body of the law." ${ }^{35}$ Indeed, imposition of these civil fines can have "a devastating potential for harm,"36 and most commentators agree that, despite their importance, punitive damages can create misincentives and distort the civil system.

Often, the amount necessary to pumish the defendant adequately and to deter the egregious conduct far exceeds that necessary to entice the plaintiff to pursue the pumitive claim. Although the plamtiff has no inherent right to receive punitive damages, ${ }^{38}$ she receives the

32. See O'Gilvie v. United States, 519 U.S. 79, 89 (1996) (holding that punitive damages are not compensation).

33. It is conceivable that the extra effort, both during discovery and at trial, would be significant. In Alaska, for example, the factfinder may award punitive damages only if "clear and convincing" evidence proves the defendant's conduct "was outrageous, including acts done with inalice or bad motives," or "evidenced reckless indifference to the interests of another person." ALASKA STAT. $\$ 09.17 .020(b)$.

34. See Mack Trucks, Inc. v. Conkle, 436 S.E.2d 635, 642 (Ga. 1993) (Benham, J., concurring in part and dissenting in part) (stating that punitive awards provide "the financial incentive for private citizens to pursue vigorously contested claims for punitive damages").

35. Fay v. Parker, 53 N.H. 342, 382 (1873). The court continued to express its dissatisfaction with the "pernicious doctrine" and eventually disallowed punitive damages altogether: "[N]ot reluctantly should we apply the knife to this deformity, concerning which every true member of the sound and healthy body of the law may well exclain,--I have no need of thee."” Id. at 397.

36. Pacific Mut. Life Ins. Co. v. Haship, 499 U.S. 1, 42 (1991) (O'Connor, J., dissenting).

37. See, e.g., Miller, supra note 10 , at 153 (arguing that punitive damages overcompensate plamtiffs and overdeter defendants, in the process impairing the credibility of the justice system).

38. See, e.g., Sumth v. Wade, 461 U.S. 30, 52 (1983) (noting that punitive damages "are never awarded as of right, no matter how egregious the defendant's conduct"); Montgoinery Ward \& Co. v. Andrews, 736 P.2d 40, 49 (Colo. Ct. App. 1987) (stating that there is no right to 
full award, if for no other reason than that "there is no one else to receive it." ${ }^{39}$ Any amount in excess of the costs of pursuing the punitive claim results in what is called the "plamtiff's windfall." The potential for receiving this windfall encourages plaintiffs to pursue unnecessary and frivolous litigation. ${ }^{40}$

At the saine time, the prospect of high punitive awards risks exorbitant punishment and overdeterrence of defendants. ${ }^{41}$ For exan1ple, sone evidence suggests that the perceived threat of high punitive danages awards forces niedical personnel to practice "defensive medicine" by ordering extraneous tests and avoiding risky treatments to reduce the risk of nralpractice liability. ${ }^{42}$ Punitive damages do not exist to bankrupt corporations or to render their services less efficient or beneficial; instead, they attempt to correct deficient behavior and render corporations more socially beneficial. Punitive damages should adequately punish the defendant, deter similar, future conduct by the defendant and others, and provide a sufficient bounty for plaintiffs to address the outrageous conduct. However, the amount of those dainages should be no more than that necessary to accomplish each goal. $^{43}$

States liave responded to the problem of excessive punitive dainages awards in a number of ways, but often to the detriment of ade-

receive exemplary damages); Mack Trucks, 436 S.E.2d at 638 (same); Shepherd Components, Inc. v. Brice Petrides-Donohue \& Assocs., Inc., 473 N.W.2d 612, 619 (lowa 1991) (same). Alaskan courts would likely agree. See infra note 130.

39. Shepherd Components, 473 N.W.2d at 619.

40. See Smith, 461 U.S. at 91 (Rehnquist, J., dissenting) (arguing that interpreting 42 U.S.C. $\$ 1983$ to permit the award of punitive damages will only exacerbate the "torrent of frivolous claims" that already arises under that statute); Miller, supra note 10, at 156 (arguing that the prospect of "limitless" puritive damages awards "creates too large an incentive to seek puritive damages"); Note, An Economic Analysis of the Plaintiff's Windfall from Punitive Damage Litigation, 105 HARV. L. REV. 1900, 1907 (1992) [heremafter Economic Analysis] (arguing that the effect of the plaintiff's windfall is to "create at least three types of mefficiencies": "provid[ing] inefficient compensation, encourag[ing] risk-seeking behavior, and misallocat[ing] legal resources").

41. See Smith, 461 U.S. at 93 (O'Connor, J., dissenting) (concluding that "permitting an award of unlimited punitive damages on the basis of recklessness will chill public officials in the performance of their duties more than it will deter violations of the Constitution.").

42. See Miller, supra note 10, at 154-55 (describing how doctors afraid of malpractice liability may order extraneous and unnecessary tests or avoid risky treatınent options in order to protect themselves from lawsuits).

43. See Transportation Ins. Co. v. Moriel, 879 S.W.2d 10, 17 (Tex. 1994) (stating that the goal of puritive damages is "to ensure that defendants who deserve to be purished in fact receive an appropriate level of purrishment, while at the same time preventing purrshment that is excessive"). 
quate punishment and deterrence. While a few states have explicitly eliminated common law punitive damages altogether, ${ }^{\text {th }}$ a greater number have imposed limits on the amount that nuay be awarded. These limits take the form of either a flat dollar cap or some ratio to compensatory damages. ${ }^{45}$ However, dollar limits risk constricting punitive awards to amounts nuch lower than is necessary to punish and deter adequately because they do not consider the specific conduct or wealth of the defendant. ${ }^{46}$

Adequate deterrence should force the tortfeasor, and others in similar positions, to internalize the harms to society caused by his conduct. ${ }^{47}$ Internalization of the costs of one's conduct, in the form of pumitive damages, is independent of the defendant's wealth. ${ }^{48}$ For example, assunie a car manufacturer discovers that its gas caps are defective and that, absent punitive damages, this will result in approximately $\$ 70$ million of hability. However, fixing the gas caps will cost

44. See N.H. REV. STAT. ANN. \$ 507:16 (1997) (outlawing punitive damages unless otherwise authorized by statute); Kewin v. Massachusetts Mut. Life Ins. Co., 295 N.W.2d 50, 55 (Mich. 1980) ("In Michigan, exemplary damages are recoverable as compensation to the plaimtiff, not as punishment of the defendant."); Distinctive Printing \& Packaging Co. v. Cox, 443 N.W.2d 566, 574 (Neb. 1989) (holding that punitive damages violate the state constitution); Dailey v. North Coast Life Ins. Co., 919 P.2d 589, 590 (Wash. 1996) (en banc) (expressing the Washington Supreme Court's "long-standing rule prohibiting punitive damages without express legislative authorization"). Connecticut allows punitive damages only to the extent of the plaimtiff's litigation costs and expenses. See Gagne v. Town of Enfield, 734 F.2d 902, 904 (2d Cir. 1984) (applying Connecticut law).

45. See Pacific Mut. Life Ins. Co. v. Haslip, 499 U.S. 1, 57 (1991) (O'Connor, J., dissenting) (stating that imposition of legislative caps "would substantially enhance the fairness and rationality of the State's punitive damages system"); supra note 10.

46. See Shores, supra note 11, at 87 (noting the mefficiency of capping punitive awards); Miller, supra note 10, at 157-58 (discussing the deficiencies of arbitrarily imposed caps on punitive awards). Althougl punitive damages should generally bear a reasonable relationship to the actual harm caused, particularly egregious conduct may support a high puritive award regardless of the compensatory amount. See BMW of North Am., Inc. v. Gore, 517 U.S. 559, 582 (1996) (concluding that a low compensatory award may support a high punitive award if "a particularly egregious act has resulted im only a small amount of economic damages" or "in cases in which the mjury is hard to detect or the monetary value of noneconomic liarm miglt liave been difficult to determine"). Indeed, the Supreme Court las refused to inpose a "mathematical briglt line" test for determining the excessiveness of a punitive damages award, Haslip, 499 U.S. at 18, and the Alaska Supreme Court agrees, see International Bhd. of Elec. Workers, Local 1547 v. Alaska Util. Constr., Inc., 976 P.2d 852, 859 (Alaska 1999) (uplooldmg a punitive award 18 times the compensatory award); Ben Lomond, Inc. v. Campbell, 691 P.2d 1042, 1048 (Alaska 1984) (holding that ratios are mere guides in evaluating excessiveness).

47. See Jolinson, supra note 14, at 533-34.

48. See id. at 533-34. The mere imposition of a punitive damages award, no matter how small, may also deter harmful conduct if the award is highly publicized. See Slores, supra note 11 , at $69-70$. 
the company $\$ 130$ million. By not fixing the gas caps, the manufacturer reasonably anticipates saving $\$ 60$ million. Thus, to deter the manufacturer from leaving the defective gas cap in place, it must be subject to a pumitive penalty of $\$ 60$ million. ${ }^{49}$ A punitive damages cap that limits the award to $\$ 500,000$ is relatively ineffective in deterring the manufacturer from putting the defective gas caps into the stream of commerce..$^{50}$

Punishment, on the other hand, requires consideration of the defendant's wealth. ${ }^{51}$ Culpable defendants may need additional pumshment beyond deterrence to impress upon them the "especially reprehensible" nature of their conduct. ${ }^{52}$ But to prevent excessiveness, the punishment can be reduced by penalties already suffered by the defendant, such as compensatory damages, attorneys' fees, and criminal fines. ${ }^{53}$

49. See Paul J. Zwier, Due Process and Punitive Damages, 1991 UTAH L. REV. 407, 427-28 (1991) (analyzing Grimshaw v. Ford Motor Co., 174 Cal. Rptr. 348 (Ct. App. 1981)). Of course, it is possible that many plaintiffs will sue a single defendant for the same conduct. If each hitigant is entitled to pursue $\$ 60$ million in punitive damages, the manufacturer will surely be overdeterred. However, if only the first plamtiff receives the punitive award, there will be a rush to the courtroom, and, more troubling, subsequent small-damages plaintiffs may not be able to finance their claims at all. See infra note 79. A split-recovery statute may ameliorate this problem by enabling the state to apportion a fraction of its share of the original punitive award to future plaintiffs. See infra note 71 . Nevertheless, it remains uncertain what effects multiple litigants might have on jurisdictions with split-recovery punitive damages allocation. It may be that subsequent litigants will be prevented from pursuing punitive damage claims because of double jeopardy concerns. See infra note 153 and accompanying text.

50. See Cox v. Stolworthy, 496 P.2d 682, 690 (Idaho 1972) ("Clearly im sucl cases the award of exemplary damages should aim at inaking the cost of sucl repetitive antisocial conduct uneconomical.").

51. See Lunsford v. Morris, 746 S.W.2d 471, 472 (Tex. 1988) ("That which could be an enormous penalty to one may be but a mere annoyance to another."). The Supreme Court has acknowledged that adequate punishment may depend upon the defendant's wealth. See TXO Prod. Corp. v. Alliance Resources Corp., 509 U.S. 443, 462 n.28 (1993) (plurality opinion) (approving consideration of the defendant's wealth in assessing punitive damages); Haslip, 499 U.S. at 22 (same). Some states specifically require consideration of the defendant's net worth when assessing punitive damages. See, e.g., Transportation Ins. Co. v. Moriel, 879 S.W.2d 10, 29 (Tex. 1994); Crookston v. Fire Ins. Exch., 817 P.2d 789, 808 (Utah 1991) (holding that the trier of fact must consider the relative wealth of the defendant when assessing punitive damages). On the other hand, taking the defendant's wealth into account may unfairly subject wealthy corporations to frivolous claims and unsympathetic juries. See J. David Tate, Comment, The American Law Institute Study on Enterprise Liability for Personal Injury: How Does Texas Tort Law Compare?, 45 BAYLOR L. REv. 103, 138-39 (1993) (arguing for the exclusion of the defendant's wealth).

52. Haslip, 499 U.S. at 54 (O’Connor, J., dissenting).

53. See Snrith v. Wade, 461 U.S. 30, 94 (1983) (O'Connor, J., dissenting) (noting that the prospect of paying compensatory damages and attorneys" fees can provide "significant deterrence"); see also Jolin L. Meredith \& Brian P. Casey, Taking Cover: Preserving Error When Hit 
Alaska's punitive daniages schenie takes both deterrence and punishment into account. To ensure proper deterrence, Alaska allows the factfinder to regard "the amount of financial gain the defendant gained or expected to gain as a result of the defendant's conduct." ${ }^{, 4}$ To reach an appropriate level of punishment, the factfinder may consider "the likelihood... that serious harm would arise," as well as "any nitentional concealment of the conduct" and "the financial condition of the defendant." 55 Finally, in order to prevent excessiveness, the factfinder may also consider other forms of deterrence or punishment that the defendant has already borne or may bear in the future. $^{36}$

Yet, Alaska also caps its punitive damages. ${ }^{57}$ Remedies for even the nost egregious wrongs cannot surpass the greater of four times the compensatory damages, four times the defendant's financial gam attributable to the conduct, or $\$ 7$ million. ${ }^{58}$ These caps, while normally keepmg punitive damages withm reason, mevitably render inadequate the ultimate penalty for some defendants' conduct. ${ }^{59}$ The Alaska legislature has sinuply decided to sacrifice some punishment in favor of eliminating punitive verdict outliers. ${ }^{60}$ At the same time, Alaska adequately addresses deterrence and punishment by permitting punitive damages up to four times the defendant's expected financial gain or $\$ 7$ million for conduct causing only nonimal damages. ${ }^{61}$

with a Claim for Punitive Damages, 47 BAYLOR L. REV. 923, $942-44$ (1995) (addressing the implications of subjecting a defendant to multiple punitive damages awards for a single act).

54. ALASKA STAT. $\$ 09.17 .020$ (c)(3) (Michie 1998).

55. Id. $\$ \$ 09.17 .020(\mathrm{c})(1), 09.17 .020(\mathrm{c})(4), 09.17 .020(\mathrm{c})(6)$.

56. See id. $\$ 09.17 .020$ (c)(7) (permitting contemplation of the "total deterrence of other damages and punishment imposed on the defendant as a result of the conduct, including compensatory and punitive damages awards to persons in situations similar to those of the plaintiff and the severity of the criminal penalties" faced by the defendant).

57. See id. $\$ \$ 09.17 .020(\mathrm{f})-(\mathrm{l})$.

58. See id. $\$ \$ 09.17 .020(\mathrm{~g})(1)-(3)$.

59. This assumes one plaintiff or class per defendant. Multiple litigants may present a separate issue that las not yet been resolved by the courts or legislature. See supra note 49.

60. See Act of May 9, 1997, ch. 26, § 1(2), 1997 Alaska Sess. Laws 1, 1 (stating that the legislative intent underlying the split-recovery statute was the provision of "reasonable, but not excessive, puritive damages awards against tortfeasors sufficient to deter conduct and practices that harm innocent Alaskans while not hampering a positive business enviroument by allowing excessive penalties").

61. The Alaska Supreme Court las "found punitive danages to be appropriate in cases where the actual losses are nominal." Barber v. National Bank, 815 P.2d 857, 864 (Alaska 1991). 
But if Alaska's caps and ratios deftly balance a limit on exorbitant punitive awards with the ability to punish and deter outrageous conduct, then why did the legislature supplenent these limits with a split-recovery clause ${ }^{62}$ More generally, why do judges almost invariably reduce higl punitive awards? ${ }^{63}$ Perhaps the answer to both questions lies in the fact that a single plaintiff, regardless of actual darnages, might pocket a windfall suin niany times more than the amount necessary to niake her whole. ${ }^{64}$

\section{B. Minimizing the Plaintiff's Windfall}

The traditional distribution of the punitive award to the plamtiff las been criticized for several reasons. First, a punitive judgment reflects society's outrage at some egregious conduct potentially harming a whole segment of the public, not just the individual plamtiff. ${ }^{65} \mathrm{~A}$ more sensible distribution would thus allocate the award to some public purpose benefiting a part of society greater than just the already-compensated plaintiff. ${ }^{66}$ Second, the prospect of excessive punitive awards creates mismcentives that can corrupt the legal system by

62. See Alaska STAT. $\S 09.17 .020(j)$.

63. Take the infamous McDonald's coffee case for example. The evidence showed that the plaintiff had spilled McDonald's hot coffee on herself, sustaining compensable damages in the amount of $\$ 200,000$. See Liebeck v. McDonald's Restaurants, P.T.S., Inc., No. CV-93-02419, 1995 WL 360309, at *1 (N.M. Dist. Ct. Aug. 18, 1994). The jury determined that the company was $80 \%$ at fault and thus awarded the plaintiff $\$ 160,000$ in compensation. See id. The jury also assessed the company punitive damages of $\$ 2.7$ million. See id. In calculating the punitive amount, the jury considered the fact that McDonald's had been told over 700 times that its coffee was too hot and that some of its customers had suffered severe burns as a result. See Samuel R. Gross \& Kent D. Syverud, Don't Try: Civil Jury Verdicts in a System Geared to Settlement, 44 UCLA L. REV. 1, 5 (1996) (citing A Burning Hot Tall Tale, HARTFORD COURANT, May 6, 1995 , at A12). The $\$ 2.7$ million figure equaled McDonald's revenue on two days' worth of coffee sales. See id. Nevertheless, the judge subsequently reduced the punitive award to a mere $\$ 640,000$. See id. Other courts have similarly reduced punitive damages awards. See, e.g., EEOC v. HEB Corp., 135 F.3d 543, 557 (8th Cir. 1998) (reducing a $\$ 4.8$ million punitive award to $\$ 480,000$ ); Martini v. Federal Nat'l Mortgage Ass'n, 977 F. Supp. $464,478-79$ (D.D.C. 1997) (reducing a $\$ 1$ million punitive assessment to $\$ 200,000)$, rev'd on other grounds, 178 F.3d 1336, 1338 (D.C. Cir. 1999).

64. In the McDonald's coffee case, see supra note 63 , the jury awarded the plaintiff punitive damages more than 13 times greater than her actual damages. See Liebeck, 1995 WL 360306 , at *1.

65. This is especially true in the case of products hability suits. See James A. Breslo, Coinment, Taking the Punitive Damage Windfall away from the Plaintiff: An Analysis, 86 Nw. U. L. REV. 1130, 1139-40 (1992) (proposing to redirect punitive awards to victorious plaintiffs that have been unable to collect from insolvent defendants).

66. Cf. id. (stating that a compensation fund would increase the number of adequately compensated plaintiffs). 
luring plaintiffs and their attorneys into unnecessary or extraneous litigation. ${ }^{67}$ Third, there just seeins to be something fundamentally unfair about a plaintiff who, after being made whole by full coinpensation, then harvests the extra benefit of an enormous punitive award. ${ }^{6 .}$

Alaska's sphit-recovery punitive scheme addresses the problem of the plaintiff's windfall, while still effectively providing adequate punishment and deterrence. ${ }^{69}$ That is, only the distribution of punitive damages has changed, not their assessinent. ${ }^{70}$ From the defendant's perspective, sphit-recovery changes nothing. At the same time, however, the funds are redistributed from the plaintiff to an entity better able to use the money for the public benefit. ${ }^{71}$ In Alaska, $50 \%$ of the punitive judginent is to be "deposited into the general fund of the state."72

67. See Smith v. Wade, 461 U.S. 30, 59 (1983) (Rehnquist, J., dissenting) ("[T]he alleged deterrence achieved by punitive damage awards is likely outweighed by the costs-such as the encouragement of unnecessary litigation ....").

68. Perhaps it is this last factor that prompted a Texas appellate court to remand a $\$ 15$ milhon punitive award for redeterminatiou by the trial court. See State Farm Mut. Auto. Ins. Co. v. Zubiate, 808 S.W.2d 590, 606 (Tex. App. 1991, writ deried). The court reasoned, "Is the evidence factually sufficient to support the trial court's judgment upholding the jury award of $\$ 15$ million in punitive damages agamst the Appellant? Our answer is no, but why? Because it just is." Id. at 605.

69. See Kevin M. Epstem, Note, Punitive Damage Reform: Allocating a Portion of the Award to the State, 13 REV. LITIG. 597, 599 (1994) ("Statutes that allocate a portion of the punitive damage award to an entity other than the plaintiff serve the goals of punishment and deterrence while combating the windfall problem by reducing the amount the plaintiff receives.").

70. See id. at 599-603. However, if the jury knows of the allocation, it could assess a greater amount to ensure that the plaintiff gets a sufficient award. On the other hand, if the jury is ignorant of the allocation, it may award less in order to avoid giving the plaintiff a windfall. See infra note 100 . Alaska's statute does not indicate whether the jury is to know of the allocation. See ALASKA STAT. $\$$ 09.17.020 (Michie 1998).

71. The government can redistribute the funds to society in a number of ways. For example, Georgia and Utah deposit the state's portion into a general revenue fund. See GA. CODE ANN. \$ 51-12-5.1(e)(2) (Supp. 1999); UTAH CODE ANN. § 78-18-1(3) (1996). With more revenue, the state can assess lower taxes, saving the public money. The state also can use the extra revenue to bolster those public works in greatest financial need, or to serve some other public purpose. For example, Missouri deposits its portion into a fund designed to compensate tort plamtiffs unable to collect judgments from insolvent defendants. See MO. ANN. STAT. § 537.675(1) (West Supp. 1998). Other states have shightly different funds. See 735 ILL. COMP. STAT. ANN. 5/2-1207 (West Supp. 1999) (State Department of Human Resources Fund); IND. CODE ANN. § 34-51-3-6(b)(2) (Michie 1998) (Violent Crimes Compensation Fund); IowA CODE ANN. $\$$ 668A.1(2)(b) (West 1998) (Civil Reparations Fund); OR. REV. STAT. \$ 18.540(1)(b) (Supp. 1998) (Criminal Injuries Compensation Account). Those states that make their portion of punitive awards available to the victims of judgment-proof defendants are best serving the purpose of the tort system-providing compensation for injuries.

72. ALASKA STAT. $§ 09.17 .020(\mathrm{j})$. 
Despite its advantages, Alaska's spht-recovery scheme is subject to several significant criticisms relating to plaintiffs' incentives to bring hitigation. While each of these criticisms has some merit, on balance Alaska's scheme is a good one.

First, by reducing the benefits of a pumitive judgment, sphtrecovery may hinder the ability of the civil justice system to address outrageous conduct. Plaintiffs may not be able to afford the added expense of pursuing a pumitive claim as part of their litigation, or they may not bring suit at all, because the prospect of a small compensatory award does not justify the costs of litigation. By "removing, or at least crippling, the financial imcentive for private citizens to pursue vigorously contested claims for pumitive dainages, the punishment and deterrence purpose of pumitive damages is greatly himdered." 73 Without private enforcers, tortfeasors may be expected to contimue their egregious wrongs with impunity. ${ }^{74}$

However, the diminished incentive to pursue punitive claims ${ }^{75}$ may actually have a positive effect. Alaska allocates half of the punitive award to the state, but half still goes to the plaintiff. Since the size of the pumitive award is often related to the wantonness of the defendant's conduct, ${ }^{76}$ the most outrageous conduct will still generate a large bounty for the plaintiff. It is only with respect to less outrageous

73. Mack Trucks, Inc. v. Conkle, 436 S.E.2d 635, 642 (Ga. 1993) (Benham, J., concurring im part and dissenting in part).

74. See id. Nonetheless, at least one commentator has championed the complete elimination of the plaintiff's uindfall. See Breslo, supra note 65, at 1133 (arguing that the entire puritive award should go to the state).

75. One cominentator disputes the notion that split-recovery will diminisli the incentive to bring suit. See Clay R. Stevens, Cominent, Split-Recovery: A Constitutional Answer to the Punitive Damage Dilemma, 21 PEPP. L. REV. 857, 862-63 (1994) (claiming that a proper allocation will not reduce the incentive to sue because the desire for compensated injuries is sufficient). But the author fails to consider two factors in his analysis. First, even if a plaintiff is compensated fully, pleading and litigating punitive claims impose additional costs on the plaintiff not covered by compensatory remedies. Second, the American Rule, see infra note 82 and accompanying text, virtually negates any assumption of full compensation anyway. In sinall claims cases, hitigation costs may exceed prospective compensatory recoveries, and thus the plaintiff lias no incentive even to bring a compensatory claim unless additional awards are available. Whether this is an appropriate objective for sphit-recovery statutes is not at issue here; rather, the simple fact is that split-allocation will force at least some potential plaintiffs not to bring suit.

76. See Day v. Woodworth, 54 U.S. 363, 371 (1852) (stating that puritive damages in tort cases are assessed "in view [of] the enormity of [the] offence rather than the measure of coinpensation to the plaintiff"). The Supreme Court has repeatedly affinned this principle. See, e.g., TXO Prod. Corp. v. Alliance Resources Corp., 509 U.S. 443, 460-61 (1993) (plurality opimion) (endorsing the cominon state court practice of considering the "Inagnitude of the potential harm" threatened or caused by the defendant's conduct when assessing punitive damages (enphasis deleted)). 
conduct that plaintiffs may anticipate a return that does not justify the costs of pursuing the pumitive claim. Thus, spht-recovery tends to discourage only those punitive claims on the frivolous end of the scale." Indeed, the Alaska legislature specifically approved of the diminished incentive as a way to weed out frivolous claims and to improve judicial efficiency. ${ }^{78}$

A second and more serious concern is that some plaintiffs with small actual dainages might be prevented from bringing suit at all without the extra lure of full puntive dainages. Often the expenses of hitigation exceed the amount awarded as full compensation. Punitive damages can provide the incentive needed to make small-injury claims profitable enough to be litigated. ${ }^{79}$ Reducing the amount of punitive damages available to the plaintiff would make some of these smaller cases unprofitable, thus keeping some meritorious claims out of the courtroom.

While it is possible that the diminished incentive created by splitrecovery will dissuade some small-damages plaimtiffs from filing suit, at least three factors amehorate this seemingly liarsh resnlt. First, if the defendant's conduct is egregious enough to warrant punitive damages at all, ${ }^{80}$ it may also entitle the planitiff to attorneys' fees, court costs, and/or treble damages. ${ }^{81}$ Second, it is a staple of American

77. Elimination of frivolous punitive claims will conserve judicial resources, not to mention those of the defendant. At the same time, meritorious punitive claims are less likely to be affected. The mitigated incentive to pursue claims is not without concerns, but it should indeed reduce the imisincentive for senseless punitive litigation. For a discussion of the potential benefits of a shight disincentive, see James E. Lee II, Casenote, Mack Trucks, Inc. v. Conkle: The Georgia Supreme Court Tells the Legislature to Keep on Truckin' When Apportioning Punitive Damage Awards to the State Treasury, 45 MERCER L. REV. 1439, 1447 (1994).

78. See Act of May 9, 1997, ch. 26, $\$ 1(1), 1997$ Alaska Sess. Laws 1, 1 (stating that one purpose of the sphit-recovery statute was to "encourage the efficiency of the civil justice system by discouraging frivolous hitigation").

79. See Note, Exemplary Damages in the Law of Torts, 70 HARV. L. REV. 517, 526 (1957) (arguing that, without the possibility of punitive damages, "fewer wrongdoers would be punished, since a plaintiff would have no inducement to bring suit if the compensatory damages were likely to be small").

80. See ALASKA STAT. $\$ 09.17 .020$ (b) (Michie 1998) ("The fact finder may make an award of purritive damages only if the plaintiff proves ... that the defendant's conduct (1) was outrageous, imcluding acts done with malice or bad motives; or (2) evidenced reckless indifference to the interest of another person." (emphasis added)).

81. Such statutory benefits are occasionally available under Alaska law. See, e.g., id. \& 09.45 .740 (providing for treble damages for waste of real property); id. $\$ 34.03 .300$ (b) (providing that a residential tenant may collect court costs and attorneys' fees, in addition to actual or statutory damages, if the landlord makes an unlawful entry or unreasonably liarasses the tenant). 
jurisprudence that eacl party normally bears lier own litigation costs. American legal jurisprudence has deemed it acceptable that certain plaintiffs legally entitled to compensation will not fight for it because the costs of the fight are too high. Finally, there are other relatively inexpensive ways to bring low-value claims. Small claims courts, arbitration forums, mediation, and Judge Judy are available. ${ }^{83}$

The final criticism of Alaska's split-recovery scheme deals with attorney imcentives. ${ }^{84}$ Many tort plaintiffs are represented by contingent-fee lawyers, whose primary incentive to take these cases is the prospect of a huge pumitive award. ${ }^{85}$ The ensumg redistribution of legal expertise ultimately results in a surfeit of attorneys chasing cases with potentially large punitive verdicts and a dearth litigating nonpumitive or small-pumitive damages cases. ${ }^{86}$ Minimizing the anticipated windfall seems the obvious solution, but too great a reduction may make it more difficult for certain plaimtiffs to secure representation. However, Alaska has anticipated this problem as well. The three-cap system limits the amount of punitive damages that may be awarded, thus limiting the attorney misincentives created by the prospect of a huge punitive judgment. ${ }^{87}$ At the same time, the split-recovery provi-

82. This maxim is called the American Rule. First articulated in Arcambel v. Wiseman, 3 U.S. (3 Dall.) 306, 306 (1796), and followed in Oelrichs v. Spain, 82 U.S. (15 Wall.) 211, 219 (1872), and Day v. Woodworth, 54 U.S. (13 How.) 363, 371-73 (1851), the rule apportioning litigation costs to each side finally became known as the American Rule in Fleischmann Distilling Corp. v. Maier Brewing Co., 386 U.S. 714, 717-18 (1967). For a general discussion of the American Rule, see John F. Vargo, The American Rule on Attorney Fee Allocation: The Injured Person's Access to Justice, 42 AM. U. L. REV. 1567 (1993).

83. See Breslo, supra note 65 , at 1152 ("Small claims courts and arbitration proceedings provide relatively inexpensive tribunals for claims that may otherwise be too costly to litigate.").

84. See generally Grube, supra note 15 , at 856 (contending that "the state should pay plaintiffs' attorueys ... for seeking punitive danages"); Parkinson, supra note 13, at 968-70 (arguing that the state should compensate the plaintiff's attorney for securing its portion of the punitive award).

85. See Economic Analysis, supra note 40, at 1909-10 (noting that sucl awards "produce abnormal profits for the lawyers involved and draw legal talent into plaintiffs" work im areas in which courts frequently award punitive damages").

86. See id. (noting that the lure of punitive damages results in a "misallocation of legal talent [that] wastes resources" by "crowd[ing] courts with marginal cases" and causing "legal resources [to be] siphoned off from other areas in which punitive damages are not available").

87. Under Alaska's statutory cap scheme, punitive awards of several million dollars may occur but cannot reasonably be expected. See supra notes 57-60 and accompanying text. In most cases, punitive damages cannot exceed the greater of $\$ 500,000$ or three times the compensatory damages. See ALASKA STAT. $\$ \S 09.17 .020(f)$ (Michie 1998). If the defendant's conduct was "motivated by financial gain and the adverse consequences of the conduct were actually known by the defendant or the person responsible for making policy decisions on behalf of the defendant," the cap increases to the greater of four times the compensatory damages, four times the 
sion permits attorneys to take their fee as a percentage of the total punitive award, before allocation to the state-thus enabling attorneys to take contingent-fee cases as before. ${ }^{88}$

Finally, Alaska's split-recovery statute also addresses fairness concerns. A RAND study lias shown that litigation costs and fees consume an average of $30 \%$ of a plaintiff's conmensatory award. ${ }^{* 9}$ Thus, awarding the planitiff $25-40 \%$ of the punitive danıages seems a fair way to conıpensate the planitiff for litigation costs. ${ }^{90}$ Alaska's allocation of $50 \%$, while a hittle generous, is still within reason. In fact, Alaska's punitive damages statute reasonably addresses all three problems associated with the plaintiff's windfall: it returns a portion of the award to the public, it reduces without eviscerating plaintiffs' and attorneys' incentives to pursue cases with viable punitive dan1-

defendant's attributable financial gain, or $\$ 7$ million. See id. $\$ 09.17 .020(\mathrm{~g})$. Finally, in unlawful employment practices cases, there are various dollar limits depending on the size of the enployer, the highest of which permits an award of punitive danages up to $\$ 500,000$ if the einployer has at least 500 employees in the state. See id. $\S 09.17 .020(\mathrm{~h})$. Hence, the caps reduce, without eliminating, the attorney's incentive to pursue only those cases likely to result in high punitive awards.

88. See id. $\$ 09.60 .080$ (providing that if punitive damages are awarded, "the contingent fee due the attorney shall be calculated before that portion of punitive damages due the state... has been deducted froin the total award of damages"). If the sphit were to occur before the attorney was paid, the attorney could expect only $30 \%$ of half of the punitive award, or a $15 \%$ fee. However, where the attorney is paid before the allocation, she will receive the full $30 \%$.

On the other hand, the timing of the attorney's payment does not affect the plaintiff's recovery. For example, suppose the punitive judgment is $\$ 100,000$ and the attorney has a $30 \%$ fee arrangement. If the dannages are allocated first, the state gets $\$ 50,000$, the attorney receives $30 \%$ of her client's reenaining $\$ 50,000$, or $\$ 15,000$, and the plaintiff retains $\$ 35,000$. Under the Alaska scheine, however, the attorney takes her cut first, receiving $30 \%$ of the full $\$ 100,000$. The remaining $\$ 70,000$ is then divided between the state and the plaintiff, leaving each with $\$ 35,000$. In either case, the plamtiff's recovery remains the same; it is only the state that goes hungry by allowing the attorney to eat first. Other states have dealt with the timing issue in different ways. See FLA. STAT. ANN. § 768.73(7) (West 1997) (calculating attorneys' fees froun the portion retained by the plaintiff) (repealed 1997); GA. CODE ANN. § 51-12-5.1(e)(2) (Supp. 1999) (deducting attorneys' fees and court costs before allocation between the state and the plaintiff); 735 ILL. COMP. STAT. ANN. 5/2-1207 (West 1992) (giving authority to the judge to determine how to allocate attorneys' fees); OR. REV. STAT. ANN. § 18.540(1)(a) (Supp. 1998) (calculating attorneys' fees from the portion recovered by the prevailing party); UTAH CODE ANN. § 78-18-1(3) (1996) (deducting attorneys' fees and costs before allocation).

89. See JAMES S. KAKALIK \& NICHOLAS M. PACE, COSTS AND COMPENSATION PAID IN TORT LITIGATION 68 (1986) ("The average tort lawsuit concluded in 1985 resulted in an estimated $\$ 7,300$ to $\$ 8,800$ in plaintiffs' legal fees and expenses, which was approximately 30 to 31 percent of total compensation paid to plaintiffs.").

90. This mathematical comparison becomes distorted if the punitive award is several times the plaintiff's actual dainages. Nonetheless, the perception of fairness is augmented when the plaintiff receives only half of the punitive award, if only because receiving the entire award appears so undeserved. 
ages claims, and it mollifies the punitive system with a hint of fairness. Although the effect of Alaska's statute on the plaintiff's windfall is not without its possible adverse consequences, on balance the benefits outweigh the potential harms.

\section{The Settlement Incentive}

Because split-recovery statutes affect parties' imcentives to sue, they also affect the incentive to settle. ${ }^{91}$ If a split-recovery mandate does not reacli settlements, ${ }^{92}$ botli sides have strong reasons to settle. ${ }^{93}$ Alaska, for example, allocates $50 \%$ of the award to the state. ${ }^{94}$ Assume that both parties in a civil case estimate that the jury will award $\$ 50,000$ in actual damages and $\$ 50,000$ in punitive damages. The plaintiff expects to gaim only $\$ 75,000,{ }^{95}$ while the defendant expects to pay the full $\$ 100,000$. Thus, both parties will favor any settlement between $\$ 75,000$ and $\$ 100,000$. The defendant will pay less than it ex-

91. See Thomas Koenig, The Shadow Effect of Punitive Damages on Settlements, 1998 WIS. L. REV. 169 (analyzing the effect of the possibility of punitive danuages on settlement negotiations); see also Punitive Damages in Financial Injury Cases-The RAND Report: Hearing Before the Senate Judiciary Comm., 105th Cong. 1 (1997) (statement of Sen. Orrin Hatch) ("[T]he very risk of bloated awards can scare defendants imto settling for excessive sums rather than risking the determination of an unsympathetic jury."). Of course, in the sphit-recovery context, the defendant does not care whether the state or the plaintiff receives the award; the prospect of paymg to either party fuels the settlement incentive.

92. A split-settlement provision would require the parties to divide a settlenent between compensatory and punitive damages, with the state receiving some portion of the latter. See Economic Analysis, supra note 40, at 1915 (argunig that any split-recovery system requires some provision "to overcome the settlement problem"). In one Florida case, after the plaintiff won a verdict including punitive damages, the parties reached a settlement whereby the plaintiff agreed to accept less than the full judgment, but the payment was characterized as purely compensatory. The state then sued to collect its portion of the punitive award, and the court found the settlement to be "a subterfuge to dispossess the [state] of its portion of the award of punitive damages" and awarded the state its portion notwithstanding the settlenient. Sontag v. State Dep't of Banking \& Fin., 669 So. 2d 283, 284 (Fla. Dist. Ct. App. 1996) (per curiam). Florida then passed a statute requiring that post-verdict settlements include the state, see FLA. STAT. ANN. \$ 768.73(4) (West 1997) ("A settlement agreement entered into between the original parties to the action after a verdict has been returned must provide a [35\%] proportionate share payable to the [state's] fund ...."), but its entire split-recovery system has since been repealed, see Act of May 24, 1997, ch. 94, § 16, 1997 Fla. Laws 571, 574.

93. See generally Grube, supra note 15 , at 875 (noting that if punitive damages are to be "awarded primarily to the State, then the parties would have an even greater imcentive to settle"); Economic Analysis, supra note 40, at 1914-15 (observing that settleinents pose the greatest threat to a split-recovery system).

94. See AlASKa STAT. $\$ 09.17 .020(j)$ (Michie 1998).

95. $\$ 50,000$ (the full compensatory award) $+\$ 25,000$ ( $50 \%$ of the $\$ 50,000$ punitive award). 
pects, and the plaintiff will capture some of the government's portion for himself. ${ }^{96}$

To some extent, such settlements contravene the very purposes of sphit-recovery statutes. For example, if the parties in the hypothetical above settle for $\$ 85,000$, the plaintiff reaps a windfall of $\$ 10,000$, and the defendant escapes $\$ 15,000$ of punishment and deterrence. Although the split-recovery statute has reduced the plaintiff's windfall by $\$ 15,000$, it lias not eliminated it, and the reduction is at the expense of underpunishmg and underdeterring the defendant. ${ }^{97}$

The Alaska legislature has weiglied the effects of split-allocation on settlements and has determined that the benefits of a greater catalyst to settle outweigh the detrimental effects of some uuderpunishment, underdeterrence, and residual windfall..$^{98}$ The incentive to settle can be extremely beneficial to both parties and to the court. For example, because plaintiffs will only get half of any punitive judgment, they are more likely to offer to drop the suit in excliange for full coinpensation-also an attractive option for defendants, who can avoid the risk of suffering liuge punitive judgments. Thus, splitrecovery regimes encourage settlements, which furthers the central purpose of the tort system: compensation for injuries. At the sanie time, settled cases consume ninimal hitigation time and expense, and conserve judicial resources. ${ }^{99}$

Having concluded that Alaska's split-recovery statute is, ou balance, desirable legislation, ${ }^{100}$ this Note turns now to the viability of

96. The illustration oversimplifies reality; punitive damages are rarely so easily approximated. Nevertheless, crude cost-benefit analyses occur even in the most complex and uncertain cases. For a detailed analysis of the econoumc incentives of both parties, see Breslo, supra note 65 , at $1158-66$.

97. Although settlements generally undercut the purposes of split-recovery statutes, they do foster partial achievement of their principles. The plaintiff does not reap as unuch windfall as she would have under a nonallocation scheme. See Epstein, supra note 69, at 618 .

98. See Act of May 9, 1997, ch. 26, §1(10), 1997 Alaska Sess. Laws 1, 2 (expressing the intention of the legislature for the split-recovery statute to "reduce the amount of litigation proceeding to trial by ... providing a financial incentive to both parties to settle the dispute"); see also Fust v. Attorney Gen., 947 S.W.2d 424, 432 (Mo. 1997) (en banc) (suggesting that the Missouri legislature might have intended a spht-recovery statute to "encourage settleinent so as to avoid the burden litigation imposes on the parties and the judicial system").

99. See Epstein, supra note 69, at 618 ("Although the state loses a chance at financial gain [when cases settle], some efficiency has been put into the system because litigation has ended.").

100. Although the problems associated with the parties' incentives, see supra notes 73-99 and accoinpanying text, are the two factors most likely to render the Alaska statute less desirable, there is at least one other potential issue that may arise-that of juror knowledge. Much has been made of the perceived influence of juror "caprice and prejudice" on verdicts. Sunith v. Wade, 461 U.S. 30, 59 (1983) (Rehnquist, J., dissenting). If the jury knows how the award will be 


\section{Alaska's statute under the United States Constitution. ${ }^{101}$}

\section{ASSESSING THE STATUTE'S CONSTITUTIONALITY}

Although Alaska's sphit-recovery punitive damages statute is both a practical and a desirable tort reform measure, it will surely be subjected to constitutional challenge. No court has yet scrutinized Alaska's statute, but a close analysis of challenges to other states' split-recovery statutes indicates that Alaska's statute would likely be upheld. As the nature of those cliallenges has depended upon whether they were brouglit by defendants or plaintiffs, this Part will discuss the constitutional concerns along those lines.

\section{A. Defendants' Attacks}

Defendants have attacked split-recovery punitive danıages statutes under a number of constitutional provisions, but each challenge is based on one argument-that spht-recovery statutes impermissibly increase the level of governmental imvolvenient. As quasi-criminal punishments, traditional punitive damages implicate the protections

allocated, it might inflate the award to make sure the plaintiff receives a substantial amount. See Honeywell v. Sterling Furniture Co., 797 P.2d 1019, 1022 (Or. 1990) (holding that informing the jury of the allocation was reversible error because it could cause the jury to determine "that a plaintiff should receive a certain annount of money and, in order to ensure that he does, to add additional amounts to pay for attorney fees and contributions to the [state]"). But see Grube, supra note 15, at 855 (suggesting that juror suspicion that the plaintiff will reap a windfall from punitive judgments actually deflates some punitive awards). A jury inay also inflate the award if it knows the inoney will go to the state for a public benefit. See Honeywell, 797 P.2d at 1022; Johnson, supra note 14, at 535 (arguing that if jurors were "aware that a portion of any punitive damages award would be returned to public use, they might conclude they had a vested interest in a larger award"). Regardless of the reason, inflated awards grant the plaintiff a windfall and excessively punish the defendant. Thus, Florida required that the jury not be told of the allocation. See FLA. STAT. ANN. $\$ 768.73$ (8) (West 1997). Other states have agreed that instructing the jury on the distribution constitutes error. See Burke v. Deere \& Co., 6 F.3d 497, 512-13 (8th Cir. 1993) (applying Iowa law); Uniroyal Goodrich Tire Co. v. Ford, 461 S.E.2d 877, 884 (Ga. Ct. App. 1995), aff'd in part, rev'd in part on other grounds, 476 S.E.2d 565 (1996); Honeywell, 797 P.2d at 1020.

On the other haud, informing the jury that the plaintiff will have to sphit the punitive award may actually help the jury focus on punishing and deterring the defendant, rather than on trying to avoid giving the plaintiff too much of a windfall. See Grube, supra note 15, at 855 ("[J]uries generally award insufficient punitive damages because they know the money goes to plaintiffs, and juries do not want to give plaintiffs a windfall ...."). More data are necessary before determining which policy best improves punitive damages fairness. In Alaska, the legislature has made no inention of juror knowledge, and the Supreme Court has yet to confront the issue.

101. Of course, the Alaska sphit-recovery statute may run afoul of the Alaska Constitution; however, this Note only addresses issues raised under the United States Constitution. 
of due process, and allocation to the state raises the level of governmental involvement to a degree that triggers the proscriptions against excessive fines and double jeopardy. Although the arguments are convincing, they fail to render Alaska's split-recovery statute unconstitutional; rather, they merely mandate safeguards that the courts can easily impose.

In general, all punitive damages involve the government to some degree. Even when imposed in a civil suit between private parties, the punitive damages are provided for by the state, either by common law or by statute, are "imposed througl the aegis of courts,", and "serve to advance governmental interests." ${ }^{, 103}$ This modest level of governinental involvement is sufficient to trigger the protections of the Due Process Clause, although not the Excessive Fines ${ }^{104}$ or Double Jeopardy Clauses. ${ }^{105}$

1. Due Process. The imposition of punitive damages does not violate the prohibition against deprivations of property without due process, ${ }^{106}$ provided that two conditions are satisfied. First, the statute or common law under which punitive damages are provided inust include sufficient safeguards agamst arbitrariness and excessiveness. ${ }^{107}$

102. Browning-Ferris Indus., Inc. v. Kelco Disposal, Inc., 492 U.S. 257, 275 (1989).

103. Id.

104. See id. at 260 ("[The] Excessive Fines Clause does not apply to awards of punitive dainages in cases between private parties.").

105. See United States v. Halper, 490 U.S. 435, 451 (1989) ("The protections of the Double Jeopardy Clause are not triggered by litigation between private parties.").

106. See U.S. CONST. anend. XIV ("No state shall ... deprive any person of life, liberty, or property, without due process of law."). In 1989, the Supreme Court first intimated that the Due Process Clause might apply to limit punitive awards. See Browning-Ferris, 492 U.S. at 276-77 ("There is sonie authority in our opinions for the view that the Due Process Clause places outer limits on the size of a civil damages award nade pursuant to a statutory sclieme .... That inquiry nust await another day." (citation omitted)); id. at 280 (Brennan, J., concurring) ("I join the Court's opinion on the understanding that it leaves the door open for a holding that the Due Process Clause constrains the inıposition of punitive damages in civil cases brought by private parties."). Two years later, the Court clarified that punitive damages are not per se nnconstitutional. See Pacific Mut. Life Ins. Co. v. Haskp, 499 U.S. 1, 17 (1991) ("[W]e cannot say that the common-law nethod for assessing punitive damages is so inherently unfair as to deny due process and be per se unconstitutional.").

107. See BMW of North Am. v. Gore, 517 U.S. 559, 575-83 (1996) (histing the reprehensibility of the defendant's conduct, proportionality to actual harm, and relationship to civil and criminal penalties for comparable misconduct as permissible factors to guide the assessment of punitive dainages); Honda Motor Co. v. Oberg, 512 U.S. 415, 432 (1994) (liolding that due process requires judicial review of punitive awards for excessiveness); TXO Prod. Corp. v. Alhance Resources Corp., 509 U.S. 443, 464 (1993) (plurahity opinion) (stating that the financial condition of the defendant is a permissible factor $\mathrm{n}$ l guiding the assessment of punitive dalnages); 
Alaska's punitive damages scheme comphes with these requirements. ${ }^{108}$ Second, in any particular case, the trier of fact must exercise its discretion "within reasonable constramts."109 Presumably, violatimg the first condition would render the procedure facially unconstitutional, while the latter would render only mdividual awards violative of due process. Alaska's punitive damages statute thus facially comphes with due process, but individual judgments may violate the Due Process Clause if "returned by a biased or prejudiced jury." 110

Although the Due Process Clause has been imvoked to attack sphit-recovery statutes, ${ }^{111}$ its protection of the defendant apphes to the fairness of the imposition of punitive damages in general, not to the fairness of the subsequent allocation between the plaintiff and the state. The issue is whether the state's deprivation of the defendant's property is procedurally fair, ${ }^{112}$ the ultimate recipient of that property is irrelevant. That is, the due process analysis for split-recovery pumtive daniages statutes is the same as that for traditional punitive damages statutes. The fact that Alaska allocates half of a punitive judgnrent to the state does not affect the defendant's procedural due process rights.

2. Excessive Fines and Double Jeopardy. By permitting the government to share in the pumitive award, sphit-recovery statutes

Haslip, 499 U.S. at 21-22 (holding that Alabama's standards of review satisfy due process by considering the hann caused or likely to result from the defendant's conduct, the degree of reprehensibility, the defendant's profit and financial position, hitigation costs, and the imposition of other criminal and civil penalties). Nevertheless, the Court has refused to "establish a multipart test and impose it upon the States, [because] the principles of federalism counsel agaimst such a course." TXO, 509 U.S. at 483 (O'Cormor, J., dissenting).

108. Alaska's punitive damages statute comports with the Supreme Court's requirements of procedural due process in three ways. It forces the plaintiff to show particularly wanton conduct at a heightened burden of proof, see ALASKA STAT. $\$ 09.17 .020$ (b) (Michie 1998) (requiring that the plaimtiff prove that the defendant's conduct warrants punitive damages by "clear and convincing evidence"), mandates a bifurcated punitive trial and specifies what evidence may be presented in each phase, see id. $\$ \S 09.17 .020$ (a), (c), and lists seven factors, generally mirroring those listed by the Court, see supra note 107 (discussing the factors histed by the Court), that the trier of fact may consider to lielp guide its assessment, see ALASKA STAT. $\$$ 09.17.020(c)(1)-(7).

109. Haslip, 499 U.S. at 20.

110. Id. at 41 (Kennedy, J., concurring).

111. See, e.g., Mack Trucks, Inc. v. Conkle, 436 S.E.2d 635, 640 (Ga. 1993) (rejecting a due process cliallenge to a split-recovery statute); Fust v. Attorney Gen., 947 S.W.2d 424, 431 (Mo. 1997) (en banc) (same); Tenold v. Weyerhaeuser Co., 873 P.2d 413, 423 (Or. Ct. App. 1994) (same).

112. See Haslip, 499 U.S. at 17-18. 
necessarily raise the level of governmental involvement in the imposition of punitive damages. The additional level of state action is sufficient to trigger the protections of both the Excessive Fines Clause ${ }^{113}$ and the Double Jeopardy Clause. ${ }^{114}$ Although neither is fatal to Alaska's spht-recovery statute, the apphication of each has certain repercussions.

In 1989, the Supreme Court made clear that the nominal level of governmental involvement in ordinary pumitive damages was insufficient to imphicate the Excessive Fines Clause. ${ }^{115}$ In Browning-Ferris Industries, Inc. v. Kelco Disposal, Inc., the Court conducted a lengthy review of the history and purpose of the Eighth Amendment, concluding that the Framers' understanding of the tern "fines" meant "payment to a sovereign as punishment for soine offense."116 Because the Amendment apphies solely to situations involving state action, ${ }^{117}$ the Court held only that punitive damages do not implicate the Clause when the government is neither a prosecutor nor a recipient, ${ }^{118}$ leaving open the question of whether the analysis would change if the government played a larger role in imposing the penalty. ${ }^{119}$ But in Austin v. United States, ${ }^{120}$ the Court rejected the notion that the Excessive Fines Clause was limited to the criminal realm, ${ }^{121}$ concluding instead that the Clause limits governmental power to exact pumishinent $^{122}$ in any forun, regardless of whether the proceeding is labeled

113. See U.S. CONST. amend. VIII ("Excessive bail shall not be required, nor excessive fines imposed, nor cruel and unusual punishments inflicted.").

114. See $i d$. amend. V ("[N]or shall any person be subject for the same offense to be twice put in jeopardy of life or limb....").

115. See Browning-Ferris Indus., Inc. v. Kelco Disposal, Inc., 492 U.S. 257, 275 (1989) (refusing to apply the Excessive Fines Clause to traditional punitive damages awards).

116. Id. at 265 .

117. See id. at 268 ("[T] he history of the Eighth Amendment convinces us that the Excessive Fimes Clause was intended to limit only those fines directly imposed by, and payable to, the government.").

118. See id. at 264 .

119. See id. at $276 \mathrm{n} .21$ (refraining from deciding whether a qui tam action, "in which a private party brings suit in the nane of the United States and shares in any award of damages," implicates the Excessive Fures Clause).

120. 509 U.S. 602 (1993).

121. See id. at 604 (holding that the Excessive Fines Clause applies to civil property forfeitures under 21 U.S.C. $\$ 881)$.

122. The test for whether an action properly qualifies as "punishment" under Austin is whether it "caimot fairly be said solely to serve a remedial purpose, but rather can only be explained as also serving either retributive or deterrent purposes." Id. at 610 (quoting United States v. Halper, 490 U.S. 435,448 (1989)). Punitive damages surely satisfy this test. See supra notes $21-43$ and accompanying text. 
civil or criminal. ${ }^{123}$ Thus, application of the Excessive Fines Clause to purntive damages depends upon whether they are imposed with the requisite degree of governmental involvement.

In another context, the Court has provided some guidance for evaluating the degree of governmental involvement. In Edmonson $v$. Leesville Concrete Co. ${ }^{124}$ the Court considered whether racially inotivated peremptory challenges in a civil case violated the Equal Protection Clause. ${ }^{125}$ In deciding whether there was sufficient state action to trigger the constitutional protection, the Court evaluated "the extent to which the actor rehes on governmental assistance and benefits, whether the actor is performing a traditional governmental function, and whether the injury caused is aggravated in a unique way by the incidents of governmental authority." ${ }^{126}$ The Court found that, because the government has created and defined the jury selection protocol and has allowed certaim jurors to be excluded fron 1 service, ${ }^{127}$ it is the authority of the government that permits the discriminatory use of peremptory challenges. Thus, the private litigant acts under the authority of the government for the purpose of selecting the jury, ${ }^{128}$ and she is subject to the nondiscrimination provisions of the Fourteenth Amendinent. ${ }^{129}$

Edmonson is an equal protection case, but the underlying state action analysis is particularly analogous to the assessnent of punitive daniages under Alaska's split-recovery statute. The state created punitive dan1ages via statute, ${ }^{130}$ assesses them through the judici-

123. See Austin, 509 U.S. at 610 ("Thus, the question is not ... whether forfeiture . . . is civil or criminal, but rather whether it is punishment.").

124. 500 U.S. 614 (1991).

125. See U.S. CONST. amend. XIV ("No State shall ... deny to any person within its jurisdiction the equal protection of the laws.").

126. Edmonson, 500 U.S. at 621-22 (citations omitted).

127. See id. at 627 .

128. See id. at 621 ("Without this authorization, granted by an Act of Congress itself, Leesville would not have been able to engage in the alleged discriminatory acts.").

129. See id. (holding that the exercise of peremptory challenges was pursuant to a course of state action).

130. Punitive damages in Alaska are born of and nurtured by governmental power; they are not awarded as a matter of right. See Nissen v. Hobbs, 417 P.2d 250, 251 (Alaska 1966) (holding that punitive damages are not awarded as a matter of right, but rather are "discretionary with the trier of fact"); see also Doe v. Colligan, 753 P.2d 144, 145-46 (Alaska 1988) (holding that a plaintiff cannot recover punitive damages from the estate of a deceased tortfeasor because the goals of punishment and deterrence would not be furthered). Punitive damages in Alaska are legislatively created fines that must be awarded nnder the statutory stipulations or not at all. See ALASKA STAT. \$ 09.17.020(b) (Michie 1998) ("The fact finder may make an award of punitive 
ary, ${ }^{131}$ and then collects a portion of the judgment. ${ }^{132}$ Although Browning-Ferris held that traditional punitive damages lacked sufficient state involvement to imphicate the Excessive Fimes Clause,${ }^{133}$ it is likely that this represents the maximum governmental involvement that would not implicate the Clanse. ${ }^{34}$ Any additional imvolvement would likely rise to a point sufficient to implicate the Clause under Austin and Edmonson. ${ }^{135}$ That addition is furnished by the allocation of part of the award to the state.

damages only if the plaintiff proves by clear and convincing evidence that the defendant's conduct [was outrageous or reckless]." (emphasis added)).

131. Alaska's power to punish in the civil context is administered by the judge or jury in the form of punitive damages imposition. Like the Edmonson peremptory challenge system, Alaska controls the method and system of punitive assessment by first drafting and subsequently amending the language of the statute prescribing the precise way the jury can award the damages. Thus, split-recovery puritive damages statutes impose punishment, at least in part, on behalf of the state. See Matthew J. Klaben, Note, Split-Recovery Statutes: The Interplay of the Takings and Excessive Fines Clauses, 80 CORNELL L. REv. 104, 141 (1994) (noting that the distinction between civil and criminal sanctions diminishes where the state receives part of a civil fine); see also Act of May 9, 1997, ch. 26, § 1(2), 1997 Alaska Sess. Laws 1, 1 (stating the legislature's intent to provide for "punitive damage awards agamst tortfeasors sufficient to deter conduct and practices that harm innocent Alaskans").

132. Alaska's mandate that the court allocate part of the award to the state turns the court into a state actor exacting punishment for the benefit of the state. See ALASKA STAT. \$ 09.17.020(j) ("If a person receives an award of punitive damages, the court shall require that 50 percent of the award be deposited into the general fund of the state."). Although the statute disavows the state's right to "file or jom a civil action to recover punitive damages," see id., the court's inandate to split the award is sufficient state action to invoke Edmonson. The court is a state actor in this case.

133. See Browning-Ferris Indus., Inc. v. Kelco Disposal, Inc., 492 U.S. 257, 275 (1989) (refusing to apply the Excessive Fines Clause to a punitive damages award in a civil case between private parties because the state "has not taken a positive step to punish, ... nor has it used the civil courts to extract large payments or forfeitures for the purpose of raising revenue or disabling some individual"). At least one commentator has argued that Browning-Ferris was wrongly decided. See McAllister, supra note 11, at 763 (criticizing Browning-Ferris as a "rigid, originalist" decision and arguing that a "primcipled, praginatic approach to the question whether the Eighth Amendment applies to punitive damages awards in civil cases between private parties strongly suggests that Browning-Ferris is wrong").

134. See Browning-Ferris, 492 U.S. at 263-64 (refusing to "go so far as to hold that the Excessive Fines Clause applies just to criminal cases," but rather holding "only that [the Excessive Fines Clause] does not constrain an award of money damages in a civil suit when the government neither has prosecuted the action nor has any right to receive a share of the damages awarded"); id. at 298-99 (O'Connor, J., concurring in part and dissenting in part) (mtimating that the Court, "by relying so heavily on the distinction between governmental involvement and purely private suits, ... suggests ... that the Excessive Fines Clause will place some limits on awards of punitive damages that are recovered by a governmental entity").

135. See James D. Ghiardi, Punitive Damages: State Extraction Practice Is Subject to Eighth Amendment Limitations, 26 TORT \& INS. L.J. 119 passim (1990) (arguing that Browning-Ferrls suggests that sphit-recovery statutes are subject to the Excessive Fines Clause); McAllister, supra note 11, 776-79 (concluding that split-recovery statutes present sufficient state involvement to 
Of course, application of the Excessive Fines Clause to Alaska's punitive damages statute does not render it facially unconstitutional ${ }^{136}$ rather, the Clause merely prohibits excessive judgments. In fact, it could be that excessive fines analysis is superfluous in light of the Supreme Court's reliance on the Due Process Clause to judge the excessiveness of individual punitive damages awards. ${ }^{137}$ On the other hand, the Due Process Clause inore appropriately addresses the facial constitutionahity of the procedural safeguards guiding the imposition of pumitive damages, while leaving room for the Excessive Fines Clause to govern whether the mdividual award is excessive in a particular case. In either case, however, it is clear that application of the Excessive Fines Clause to Alaska's split-recovery punitive damages statute does no more for the defendant than guard against excessively high individual awards.

The analysis is similar for the Double Jeopardy Clause of the Fifth Amendment, which prevents the state from subjectimg a defendant to repeated and excessive litigation. ${ }^{138}$ Application of the Clause requires that the action be punishment imposed by the government, ${ }^{139}$

implicate the Excessive Fimes Clause); Klaben, supra note 131, at 107 (same). However, several state courts have relied exclusively on Browning-Ferris, while ignoring Austin and Edmonson, to Lold the Eighth Amendment mapplicable to their split-recovery statutes. See, e.g., Spaur v. Owens-Corning Fiberglas Corp., 510 N.W.2d 854, 868-69 (Iowa 1994) (holding the Eighth Amendment inapplicable to a split-recovery statute because the funds awarded to the state were deposited into a civil reparations fund rather than the state's general treasury); Tenold v. Weyerhaeuser Co., 873 P.2d 413, 423-24 (Or. Ct. App. 1994) (holding the Eight Amendment inapplicable to a split-recovery statute because the level of governmental involvement did not rise to that of a criminal proceeding). Because none of these decisions cited Edmonson or Austin, their holdmgs are almost certainly misguided. Other courts have handled the issue differently. For example, a Georgia federal district court held that allocation to the state transformed the civil remedy into a criminal fine, thus implicating excessive fines analysis under Browning-Ferris. See McBride v. General Motors Corp., 737 F. Supp. 1563, 1576-78 (M.D. Ga. 1990). That court, however, arguably considered an issue that the plaintiff had no standing to raise; it was the defendant whose rights were allegedly impinged by excessive fines, not the plaintiff's. See Epstein, supra note 69 , at 605 .

136. Commentators analyzing other sphit-recovery statutes have reached similar conclusions. See, e.g., McAllister, supra note 11, at 783 (discussing Georgia's split-recovery statute).

137. See Pacific Mut. Life Ins. Co. v. Haslip, 499 U.S. 1, 18-24 (1991) (rejecting a due process challenge to a punitive award because the jury assessinent was properly guided by the trial court's instructions and was subjected to post-trial and appellate review); id. at 18 (concluding that "the Due Process Clause [does not] render] the punitive dainages award in this case constitutionally unacceptable").

138. See Brown v. Ohio, 432 U.S. 161, 164-66 (1977) (describing the protections against double jeopardy).

139. See United States v. Halper, 490 U.S. 435, 447 (1989) (stating that the question of whether the Double Jeopardy Clause has been violated requires consideration of "the claracter of the actual sanctions imposed on the individnal by the machinery of the state"). 
but it is not confined to those sanctions labeled as "criminal."14"

Punitive damages surely fall withm the definition of a sanction that can only be described as punishment, ${ }^{141}$ the nore difficult issue is whether there is sufficient state action. Traditional pumitive damages do not imphicate double jeopardy because the degree of state involvement does not rise to a sufficient level. ${ }^{142}$ But, just as with the excessive fines analysis, ${ }^{143}$ Edmonson suggests that the collection of a portion of the punitive award by the state, along with its creation and imposition of the award, raises the level of governmental involvement to a point sufficient to bring sphit-recovery punitive damages withm the purview of the Double Jeopardy Clause.

The application of double jeopardy protections makes sense fronı a policy perspective as well. Defendants should not be overdeterred or excessively punished. Assuming that a criminal prosecution for the egregious offense adequately punishes and deters, plaintiffs should be prevented from obtaining pumitive damages. ${ }^{145}$ Of course, double jeopardy applies only when the government subjects the defendant to separate pumishments for the same offense. ${ }^{146}$ Thus, if a successful criminal prosecution for the egregious conduct precedes a plaintiff's punitive claim, double jeopardy bars the punitive claim. ${ }^{147}$

140. See id. ("[T] he labels 'criminal' and 'civil' are not of paramount importance."). The Court stated that the "omission of the qualifying adverb 'criminally' from the formulation of the prohibition against double punishment suggests, albeit indirectly, that 'punishment' indeed may arise from either criminal or civil proceedings." $I d$. at 443.

141. See id. at 443,449 (stating that "a civil sanction, in application, may be so divorced from any remedial goal," that it can be fairly characterized only "as a deterrent or retribution," and so constitute punishment for the purpose of double jeopardy analysis); see also id. at $447 \mathrm{n} .8$ ("As the name indicates, punitive damages, available in civil cases, serve punitive goals.").

142. See, e.g., id. at 451 ("The protections of the Double Jeopardy Clause are not triggered by hitigation between private parties.").

143. See supra notes $124-35$ and accompanying text.

144. At least one state supreme court has applied Halper to split-recovery regimes. See Spaur v. Owens-Corning Fiberglas Corp., 510 N.W.2d 854, 869 (Iowa 1994) (holding that the state's receipt of a portion of the punitive judgment was insufficient state involvement to implicate the Double Jeopardy Clause, which requires that the action be criminal or quasi-criminal (citing Browning-Ferris Indus., Inc. v. Kelco Disposal, Inc., 492 U.S. 257 (1989))). However, the court's analysis is flawed because it fails to appreciate the significance of Austin and Edmonson.

145. This is because the purposes of punitive damages are to punish and deter, not to benefit the plaimtiff. See supra notes $21-28$ and accompanying text.

146. See Halper, 490 U.S. at 451.

147. This is the question specifically left open in Halper, 490 U.S. at 450 ("Nothing in today's ruling precludes the Government from seeking the full civil penalty against a defendant who previously has not been punished for the same conduct, even if the civil sanction imposed is punitive. In such a case, the Double Jeopardy Clause smiply is not implicated."). 
Alternatively, if a plaintiff succeeds on a punitive damages claim, double jeopardy prevents the government fronı prosecuting that same conduct $\mathrm{m}$ a separate proceeding. ${ }^{148}$ While at first glance this scenario appears to cede inuch power to civil plaintiffs in preenupting criminal sanctions, three factors mitigate that concern. First, under the Speedy Trial Act, ${ }^{149}$ civil suits are unlikely to conclude before criminal suits for the same conduct..$^{150}$ Second, pumitive damages are often awarded when no criminal hability can be imposed-for exanuple, against a corporate entity. ${ }^{151}$ Third, punitive damages suits might be a more effective sanction than whatever criminal penalty exists. ${ }^{152}$

Once a plaintiff succeeds on a punitive damages claim, double jeopardy also prevents future planitiffs fromı recovering punitive damages from the saine defendant for the same conduct. Because in each of these situations the first successful punishment for the defendant's conduct obviates the need for further punishnient, the Double Jeopardy Clause helps prevent overpunishment and overdeterrence of the defendant on a case-by-case basis. ${ }^{153}$

Thus, the Due Process, Excessive Fines, and Double Jeopardy Clauses all serve to prevent an Alaskan punitive daniages award fronı overpunishimg and overdeterring the defendant. Even without the

148. However, nothing in the Constitution prevents the government from joining the two actions together. See Halper, 490 U.S. at 450 ("Nor does the decision prevent the Government from seeking and obtaining both the full civil penalty and the full range of statutorily authorized criminal penalties in the same proceeding."). In that case, "the inultiple-punishment issue would be limited to ensuring that the total punishment did not exceed that authorized by the legislature." Id.

149. 18 U.S.C. $\$ 3161$ (c) (1994) (requiring that federal criminal trials counınence within seventy days of the filing of the indictment).

150. See Carl Tobias, Filling the Federal Appellate Openings on the 9th Circuit, 19 REv. LITIG. 233, 238-39 (2000) ("[S]oune district judges have not conducted trials in any civil lawsuits during the past two years, a phenomenon that can partly be attributed to the requirement in the Speedy Trial Act that judges promptly resolve criminal cases.").

151. See Thoinas Koenig \& Michael Rustad, "Crimtorts" as Corporate Just Deserts, $31 \mathrm{U}$. MICH. J.L. REFORM 289, 306 (1998) (noting the "expanded use of progressive punitive sanctions against corporations").

152. Punitive damages can be tailored to the punishment and deterrence needed for the particular defendant, see supra notes 44-56 and acconpanying text, and the imposition of punitive damages does not require nieeting the stringent burden of proof of the criminal law, see ALASKA STAT. $\$ 09.17 .020$ (b) (Michie 1998) (requiring that the plaintiff prove that the defendant's conduct warrants punitive damages by "clear and convincing evidence").

153. The Alaska statute arguably provides greater protection against double jeopardy than the Court required in Halper. In assessing punitive dainages, the factfinder may consider "the total deterrence of other daniages and punishment inposed on the defendant as a result of the conduct, including... the severity of the criminal penalties to which the defendant has been or niay be subjected." ALASKA STAT. \$09.17.020(c)(7) (Michie 1998). 
sphit-recovery clause, the safeguards required by due process ensure a fair assessment of punitive damages. The additional level of governmental involvement provided by the spht-recovery clause implicates the other two constitutional provisions. The proscription against excessive fines helps guard agamst those unfair pumitive damages awards that shp through the due process cracks, and double jeopardy queries whether, based on the defendant's previous punishment for the same offense, the plaintiff is barred from bringing a punitive damages action $\mathrm{m}$ the first place. None of these challenges, however, renders Alaska's spht-recovery punitive damages statute facially unconstitutional.

\section{B. Plaintiffs' Attacks}

Defendants are not alone in their challenges to the validity of sphit-recovery pumitive damages statutes. Plaintiffs have also brought constitutional challenges, generally contending that the government is improperly depriving them of their right to the full pumitive damages award in violation of the Takings and Due Process Clauses. But plaintiffs generally have no property right to pumitive damages until after the entry of judgment, precisely the moment when the court usually makes the allocation to the state. Thus, the Alaskan sphit-recovery statute should withstand both constitutional attacks.

The Takings Clause of the Fifth Amendment prohibits the government from taking private property for public use without compensatimg the owner. ${ }^{154}$ Obviously, Alaska does not compensate the plaintiff for its allocated half, so the issue is whether the portion allocated to the government was ever the plaintiff's property. ${ }^{155}$ Similarly, the Due Process Clause of the Fourteenth Amendment limits the government's ability to infringe on certain substantive rights. ${ }^{156}$ But to

154. See U.S. CONST. amend. V ("[N]or shall private property be taken for public use, without just compensation.").

155. See Stevens, supra note 75 , at 872 ("[S]tate action inay not constitute a taking where the plamtiff never obtains a right to the specific damage award."); $c f$. McCullough v. Virginia, 172 U.S. 102, 123 (1898) (stating, in general terms, that if a judgment has been properly entered, then the plaintiff has "a vested right, which no state legislation could disturb").

156. The concept of substantive due process is not supported by the text of the Constitution, nor easily understood. It has been defined as asking the question whether "the government's deprivation of a person's life, liberty or property is justified by a sufficient purpose. Procedural due process, by contrast, asks whether the government has followed the proper procedures when it takes away life, liberty or property." Erwin Chemerinsky, Substantive Due Process, 15 TOURO L. REV. 1501, 1501 (1999). 
implicate substantive due process interests, the right infringed must be one im which the imdividual has "more than a unilateral expectation of it. He must, mstead, have a legitimate claim of entitlement to it."157 That is, just as with the Takings Clause, the plaintiff's rights only extend to those things that are his property. ${ }^{158}$ Since states can abolish pumitive damages altogether by repealing the statute that authorizes them, they do not become the plaintiff's property until the entry of judgment. ${ }^{159}$ Thus, as long as the spht-recovery statute gives the state an interest in the punitive award before it vests in the plaintiff by judgment, there is no taking. ${ }^{160}$

Nevertheless, the Colorado Supreme Court has held that its sphtrecovery statute "effectuates a forced taking of the judgment creditor's property interest in the judgment."161 Characterizing "a judgment for exeniplary damages . . . as a property interest,"162 the court held that the statute's "disavowal ... of any state interest in a claim for exemplary damages 'at any time prior to payment becoming due' is an imphicit legislative acknowledgment of the property imterest created in the judgment creditor by virtue of the judgment itself." 163 Because the statute characterized the plaintiff as the sole judgment creditor,

\footnotetext{
157. Board of Regents v. Roth, 408 U.S. 564, 577 (1972).

158. See Stevens, supra note 75 , at 878 ("Because courts generally hold that a plaintiff secures no vested property right in a punitive damage claim, most sphit-recovery statutes ... do not violate due process." (footnote ormitted)). For the same reasons, plaintiffs have no procedural due process claims. Since they have no property right in the state's portion of the punitive award, they are not being "deprived" of anything, and there is no basis to challenge the procedures by which the state obtains the award.

159. See Pacific Mut. Life Ins. Co. v. Haskp, 499 U.S. 1, 39 (1991) (Scalia, J., concurring) ("State legislatures and courts have the power to restrict or abohish the common-law practice of punitive damages ...."); Gordon v. State, 608 So. 2d 800, 801 (Fla. 1992) (per curiam) (holding that the recovery of punitive dannages "is subject to the plenary authority of . . the legislature," which "may place conditions upon such a recovery or even abohish it altogether").

160. See Klaben, supra note 131, at 119-24 (stating that the issue is whether the punitive award has matured into a full property interest).

161. Kirk v. Denver Publ'g Co., 818 P.2d 262, 264 (Colo. 1991).

162. Id. at 267.

163. Id. Whether the legislature actually meant to create a property interest is debatable. Perhaps the legislature simply was trying to ensure the state had no way to meddle in civil affairs.
} 
forced to yield a portion of his award to the state, ${ }^{164}$ the allocation violated the Takings Clause. ${ }^{165}$

Most state constitutions accord plaintiffs a right to redress for legally cognizable injuries, ${ }^{166}$ a right courts often characterize as a property interest. ${ }^{167}$ Accordingly, plaintiffs have a vested property right in expected coinpensatory dainages before judgment. ${ }^{168}$ In contrast, punitive dainages are not for redress of injuries, but solely for punishinent and deterrence of the defendant. ${ }^{169}$ Therefore, plaintiffs have no inherent or property right in an expected punitive dainages award; ${ }^{170}$ rather, the award becomes plaintiff's property only at the entry of judgment. ${ }^{171}$

164. See COLO. REV. STAT. ANN. \$ 13-21-102(4) (West 1987) ("Nothing in this subsection (4) shall be construed to give the general fund any interest in the claim for exemplary damages or in the litigation itself at any time prior to payment becoming due."), invalidated in Kirk, 818 P.2d at 265 (holding that the statute violated the federal and state constitutions).

165. Because the court found a takings violation, it did not reach the plaintiff's substantive due process claim. See Kirk, 818 P.2d at 265 n.3.

166. See, e.g., Colo. CoNST. art. II, $\$ 6$ ("Courts of justice shall be open to every person, and a speedy remedy afforded for every imjury to person, property, or character ....").

167. See Capital Nat'l Bank v. McDonald's Corp., 625 F. Supp. 874, 879 (S.D.N.Y. 1986) (stating that a "portion of an expected recovery in a pending lawsuit is ... assignable" as a form of intangible property); Paul F. Kirgis, The Constitutionality of State Allocation of Punitive Damage Awards, 50 WASH. \& LEE L. REv. 843, 849-50 (1993) (stating that the cause of action gives a person the right to seek judicial remedy (citing Woodfork v. Marine Cooks \& Stewards Umion, 642 F.2d 966, 971 (5th Cir. 1981))). Indeed, the Kirk decision rests on this premise as an established point of Colorado law. See Kirk, 818 P.2d at 267 (reasoning that because the term "property" imcludes a legal right to recover damages for an mjury, it must also mclude the judgment that satisfies the right to recovery (citing Rosane v. Senger, 149 P.2d 372, 375 (Colo. 1944))).

168. See Kirgis, supra note 167 , at $849-50$.

169. See id. at 850-51.

170. See, e.g., Ross v. Gore, 48 So. $2 \mathrm{~d} 412,414$ (Fla. 1950) ("The right to have pumitive damages assessed is not property; and ... until a judgment is rendered, there is no vested right in a claim for punitive damages."). The dissent in Kirk recognized this point. See Kirk, 818 P.2d at 274 (Rovira, C.J., dissenting) ("[A] claim for exemplary damages is a statutory right which may be conditioned by the legislature and thus the entire judgment never vested in the plaimtiff.").

171. The punitive damages situation is analogous to a United States Supreme Court enployment case, Board of Regents v. Roth, 408 U.S. 564 (1972). In Roth the Court held that Roth's expectation of continued employment did not solidify into a property interest until actually vested in him by virtue of a contract. See id. at 578 . Finding no property interest in the reasonable expectation of future einployment, the Court reasoned that Roth's right to employment instead was created and defined by the terms of his current contract. See id. ("[R]espondent's 'property' interest in employment ... was created and defined by the terms of his appointinent."). Similarly, a plaimtiff has no inherent right to punitive damages, and thus his property interest in them is defined by the statute (in this case, the split-recovery statute) that gives him the authority to receive them. The plaintiff gets the limited right to sue for punitive damages, but only under the terms of the statute, which has designated the plaintiff's potential for receipt 
However, a system in which the plaintiff is the sole judgment creditor of the punitive award before the state takes its share probably does give the plaintiff a property right to the entire judgment. The Kirk majority correctly determined that the Colorado statute created an impermissible taking by permitting the state to collect from the plaintiff's property, already vested by judgment. ${ }^{172}$ A plaintiff has no inherent right to punitive damages, but she does have a property right to her judgment once entered. Had the Colorado legislature given the state a right to its allocated portion at or before judgment, it would have avoided constitutional problems. The supreme courts of Florida, ${ }^{173}$ Iowa, ${ }^{174}$ Missouri, ${ }^{175}$ and Georgia ${ }^{176}$ have followed this rationale in upholding their sphit-recovery statutes im the face of takings and due process challenges, and commentators generally agree. ${ }^{17}$

of only part of a punitive verdict. See Kirgis, supra note 167, at 855 .

172. The Colorado split-recovery clause required the defendant to pay one-third of any punitive judgment to the state and the remaining two-thirds to the plaintiff. See CoLO. REV. STAT. ANN. \& 13-21-102(4) (West 1987), invalidated in Kirk, 818 P.2d at 265 (holding that the statute violated the federal and state constitutions). But the statute explicitly disclaimed any governmental "interest in the claim for exemplary damages or in the litigation itself at any time prior to payment becoming due." Id.

173. See Gordon v. State, 608 So. 2d 800, 801-02 (Fla. 1992) (per curiam) (holding that punitive damages are only granted as a matter of public policy and that the legislature may modify that policy at its discretion). The Gordon dissent sympathized with the najority in Kirk, see id. at 803 (Shaw, J., concurring in part and dissenting in part), but the facts of Gordon make the dissent's conclusion ambiguous. The original judgment in Gordon madvertently omitted the state as a judgment creditor, as required under the statute. When that occurred, the plaintiff arguably became vested with a property right in the punitive award, albeit erroneously, that was then taken from him when the correction was made. It is unclear whether the dissent objected to the state's role as a judgment creditor in general, or only in the context of the unique error that occurred in Gordon. Cf. Finley v. Empiregas, Inc., 28 F.3d 782, 784-85 (8th Cir. 1994) (applying Missouri law) (finding no anthorization for the state to correct a similar situation in which the court inadvertently neglected to enter judgment for the state for its share of the punitive award).

174. See Slrepherd Components, Inc. v. Brice Petrides-Donohue \& Assocs., 473 N.W.2d 612, 619 (Iowa 1991) (stating that the "plaintiff is a fortuitous beneficiary of a punitive damage award simply because there is no one else to receive it" and thus lolding that the Fourteenth Amendinent did not apply because the plaintiff had no right to the award prior to judgment).

175. See Fust v. Attorney Gen., 947 S.W.2d 424, 431 (Mo. 1997) (en banc) (rejecting the plamtiff's claim of a denial of a property right without due process of law because no property right liad vested).

176. See Mack Trucks, Inc. v. Conkle, 436 S.E.2d 635 (Ga. 1993) (rejecting a takings challenge because the statute distributed a specific portion to the plaintiff and a separate portion to the state and thus the plaintiff had no right to the state's share).

177. See, e.g., Epstein, supra note 69, at 614 ("Since the plaintiff would not have a right to the property until the judgment, there would be no unconstitutional taking."); Grube, supra note 15, at $873-74$ (arguing that no takings issue is presented because the plaintiff never acquires a vested property right in the state's share of the judgment). 
Although no Alaskan court has addressed the issue, it is likely that Alaskan plaintiffs are never vested with the state's allocated portion of a punitive damages award. Alaskan plaintiffs have no inherent right to punitive damages before the entry of judgment, ${ }^{178}$ and the statutory allocation occurs at the inoinent of entry of the judgment. ${ }^{179}$ If the jury renders a punitive verdict, the court, under the statute's directive, enters judgment for the plaimtiff for one half and for the state for the other half. ${ }^{180}$ The plaintiff acquires a property right upon entry of judgment only to his half of the verdict. ${ }^{181}$ Consequently, the other half is never his property, and its allocation to the state neither effects an unconstitutional taking nor violates his substantive due process rights.

\section{Other Constitutional Considerations}

A few courts have considered whether split-recovery statutes violate the Equal Protection Clause. ${ }^{182}$ While some of the statutes allow certain classes of plaintiffs to receive the full punitive award but dictate that others abide by the split-allocation, ${ }^{183}$ Alaska mandates a

178. See supra note 130 (demonstrating that plaintiffs have no inherent right to punitive damages); cf. Mack Trucks, 436 S.E.2d at 639 (reaching the same conclusion under the Georgia statute); Shepherd Components, 473 N.W.2d at 619 (reaching the same conclusion under the Iowa statute).

179. See ALASKA STAT. $\$ 09.17 .020(j)$ (Michie 1998) ("If a person receives an award of punitive dainages, the court shall require that 50 percent of the award be deposited into the general fund of the state."); cf. Mack Trucks, 436 S.E.2d at 639 (applying a similar provision in the Georgia statute); Fust, 947 S.W.2d at 431 (applying a similar provision in the Missouri statute).

180. The allocation occurs after any attorneys' fees have been paid. See ALASKA STAT. $\S$ 09.60 .080 ; see also supra note 88 . Interestingly, allowing the attorney to take a contingent fee before allocation presents somewhat of a paradox. If only half of the award vests in the plaintiff, and the contingent fee arrangement is a contractual one based on the plaintiff's recovery, there seenis to be no basis for the attorney's recovery of a percentage on the state's portion. It is unclear how the paradox will be resolved, if at all, but one solution might be for the state to characterize the attorney's percentage of its portion separately from the plaintiff's contractual arrangement. The attorney gets the contracted percentage of the plaintiff's portion, and the state honors the attorney's efforts by implicitly agreeing to the same terms under a quantum meruit theory.

181. Cf. Mack Trucks, 436 S.E.2d at 639 ("A plaintiff has no vested property right in the anount of punitive damages which can be awarded in any case."); Fust, 947 S.W.2d at 431 (explaining that the effect of a split-recovery statute was that, when the plaintiffs' "claims for punitive damages ... arose, they acquired no inore than a $50 \%$ interest in such judgment as would be entered").

182. See U.S. CONST. amend. XIV, $\S 1$ ("No State shall ... deny to any person within its jurisdiction the equal protection of the laws.").

183. The Georgia statute, for example, nandates a split-allocation for punitive damages assessed for products liability claims but not for other claims. See GA. CODE ANN. \$\$ 51-12-5.1(e)- 
split-allocation for all plaintiffs seeking punitive damages. ${ }^{184}$ Thus, the Equal Protection Clause poses no threat to the constitutionality of Alaska's sphit-recovery statute.

Others have argued that split-recovery statutes subvert the hitigant's Seventh Amendment right to trial by jury. ${ }^{185}$ Under this theory, keeping the allocation percentages secret fron the jury "prevents the jury fron performing its proper function," 186 since it "is the jury's function to determine the amount of punitive damages." 187 However, this reasoning is flawed. The jury's role in assessing compensatory

(f) (Supp. 1998). Products liability plaintiffs are thus treated differently than other plaintiffs. See McBride v. General Motors Corp., 737 F. Supp. 1563, 1570 (M.D. Ga. 1990) (holding that the Georgia statute violates the Equal Protection Clause because "no fair and substantial relationship exists upon which to base such a distinction"). However, the Georgia Supreme Court later lield that the statute was permissible because, while it treated parties "in various tort actions differently," nevertheless "all similarly situated plaintiffs and defendants, including those in product liability actions, are treated equally ...." Mack Trucks, 436 S.E.2d at 639 . Other courts have summarily rejected equal protection challenges. See Gordon v. State, 608 So. 2d 800, 802 (Fla. 1992) (per curiam) (rejecting an equal protection clallenge without discussion); Fust, 947 S.W.2d at 431-32 (finding that the different treatunent accorded punitive dainages recovered by judginent and those obtained through settlement is rationally related to legitimate governmental purposes, all that is required to withstand an equal protection challenge when the legislation does not einploy suspect classifications or impinge on fundainental rights).

184. The plain language of the statute applies to all types of plaintiffs. See ALASKA STAT. $\$$ 09.17.020(a) (Michie 1998) (referring to "an action in which a claim of punitive damages is presented...."). In addition, the conspicuous absence of any reference to the word "tort" is suggestive. See id. $\$ 09.17 .020$ (a)-(j). By contrast, the immediately preceding section limiting noneconomic damages applies only "[i]n an action to recover damages for personal mjury or wrongful death." Id. § 09.17.010(a). But see Act of May 9, 1997, cl. 26, § 1, 1997 Alaska Sess. Laws 1,1 (evincing legislative intent of addressing tortious injuries). The lone exception to the split-recovery scheme is federal admiralty cases, which fall under a different set of regulations. See id. $\$ 11$.

185. U.S. CONST. amend. VII ("In Suits at common law ... the right of trial by jury shall be preserved ....").

186. Gordon, 608 So. 2d at 804 (Sliaw, J., concurring in part and dissenting in part). Muclı of the debate has focused on the practicality of disclosing the allocation to the jury. See supra note 100 .

187. Gordon, 608 So. $2 \mathrm{~d}$ at 804 (Shaw, J., concurring in part and dissenting in part). The majority in Gordon found no constitutional infirmity on this issue. See id. at 802. And, in State v. Moseley, 436 S.E.2d 632, 634 (Ga. 1993), the Georgia Supreme Court explicitly rejected the Gordon dissent's logic. In that case, the court asserted that the plaintiffs sued for punitive damages under a statute entitling thein to $25 \%$ of a jury assessment, and thus they received a jury trial on the amount to which they were entitled. See id. Moseley's persuasive reasoning will probably prevail in a Seventh Amendinent cliallenge to Alaska's statute, and Alaskan courts are unlikely to conclude that the statute hinders the right to trial by jury. See Janet V. Hallalian, Social Interests Versus Plaintiffs' Rights: The Constitutional Battle over Statutory Limitations on Punitive Damages, 26 LOY. U. CHI. L.J. 405, 442-43 (1995) ("[T]he Supreme Court, as well as state courts, would likely find that plaintiffs [do not] lave ... a right to a jury trial on punitive dainages."). 
damages is indeed to determine the amount to which the plaintiff is entitled; its role in assessing punitive damages, however, is to determine an anount that will adequately pumsh and deter the defendant. The recipient of the award has no bearing on that analysis.

Fimally, the Missouri sphit-recovery statute has been analyzed under the doctrine of separation of powers. ${ }^{188}$ In Fust v. Attorney General, ${ }^{199}$ the Missouri Supreme Court rejected a plaintiff's argument that the statute allowed the legislature to interfere impermissibly with the judiciary's "power to enforce judgments as they are entered." "son The court concluded that the legislature has the power to impose limits on common law causes of action, including the statutory allocation of punitive awards. ${ }^{191}$ In Alaska, punitive dainages are created by statute, ${ }^{192}$ not by the common law. Thus, the spht-allocation at issue here is even less mvasive of the judicial power than that in Fust.

\section{CONCLUSION}

The calls for tort reform, both im Alaska and elsewhere, have been vociferous. Often the calls focus on the pandemic of excessive punitive damages awards. Pumitive danages serve the important functions of punishing wanton conduct and deterring future similar conduct. However, because they are traditionally awarded to the plaintiff as a windfall gain, pumitive damages create mismcentives that entice the plaimtiff to seek pumitive damages regardless of whether they are warranted. Defendants are then forced to spend time and money defending these claims, and they often alter their conduct based on a fear of unjustified but severe judgments. Courts are also forced to devote scarce resources to resolving these claims.

Alaska's sphit-recovery statute, by forcing the plaintiff to split the punitive award with the state, reduces the incentive to assert punitive claims to a level more in tune with their original intent-pumishing and deterring only the most egregious conduct. The plaimtiff, presumably made whole by compensatory damages, receives half of the

\footnotetext{
188. See Finley v. Empiregas, Inc., 28 F.3d 782 (8th Cir. 1994) (applying Missouri law); Fust, 947 S.W.2d at 430 .

189. 947 S.W.2d 424 (Mo. 1997).

190. Id. at 430 .

191. See id. at 430-31.

192. See ALASKA STAT. $\$ 09.17 .020$ (b) (Michie 1998) ("The fact finder may make an award of punitive damages only if the plaintiff proves by clear and convincing evidence that the defendant's conduct [was outrageous or reckless].").
} 
punitive judgnient as a reward for her service as a private attorney general. The other half of the punitive award goes to the state to use for the public benefit. Not only is the statute practical and desirable, but it also should withstand the onslaught of constitutional challenges that have plagued other states' split-recovery statutes. While not a panacea, Alaska's sphit-recovery statute has the potential to be a valuable tool for instilling fairness and efficiency nito its tort system. 